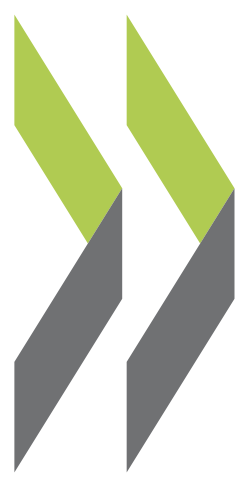

OECD Economics Department Working Papers No. 719

Improving the Functioning of the Slovenian Labour Isabell Koske Market 
Organisation de Coopération et de Développement Économiques

Organisation for Economic Co-operation and Development

12-Nov-2009

ECONOMICS DEPARTMENT

English - Or. English

Cancels \& replaces the same document of 03 August 2009

IMPROVING THE FUNCTIONING OF THE SLOVENIAN LABOUR MARKET

ECONOMICS DEPARTMENT WORKING PAPER No 719

By Isabell Koske

All Economics Department Working Papers are available through OECD's internet web site at www.oecd.org/eco/working_papers 


\section{ABSTRACT/RÉSUMÉ}

\section{Improving the functioning of the Slovenian labour market}

Labour market outcomes have improved markedly in the past years as the beneficial effects of the economic upswing were reinforced by important structural reforms. With the economy on the verge of a severe economic downturn, it is important to avoid alleviating measures that adversely affect the functioning of the labour market in the long run. Moreover, several structural challenges remain which require further reform efforts. Firstly, to raise labour force participation of the elderly the pension system needs to be reformed by removing incentives for early retirement and facilitating gradual exits from the labour force. Secondly, to increase employment rates of younger age cohorts, the length of tertiary studies needs to be reduced by strengthening incentives for rapid graduation. Moreover, potential negative employment effects associated with the relatively high minimum wage compared to the average wage should be avoided. Thirdly, to combat increasing labour market dualism, employment protection legislation on regular work contracts needs to be eased once the current economic crisis subsides and the preferential treatment of student work should be phased out. This Working Paper relates to the 2009 OECD Economic Survey of the Slovenia (www.oecd.org/eco/surveys/slovenia).

JEL classification: J21; J22; J32; J26.

Keywords: Slovenia ; labour force participation ; labour market dualism.

$* * * * * * * * * * *$

\section{Améliorer le fonctionnement du marché de travail de la Slovénie}

La situation du marché du travail s'est nettement améliorée ces dernières années, sous l'effet cumulé du redressement économique et d'importantes réformes structurelles. Face à la menace imminente d'un ralentissement économique grave, il est essentiel d'éviter toute mesure de soutien qui pourrait nuire au bon fonctionnement du marché du travail à terme. Des efforts restent en outre à fournir en matière de réformes pour remédier à certaines difficultés structurelles. Tout d'abord, le régime de retraite doit être remanié afin d'améliorer le taux d'activité des travailleurs âgés, en éliminant les incitations à la retraite anticipée et en facilitant la sortie progressive de la population active. Ensuite, pour stimuler l'emploi des jeunes, il faut réduire la durée des études supérieures, en renforçant les mesures d'incitation à l'obtention rapide des diplômes, et éviter par ailleurs les effets potentiellement négatifs sur l'emploi du niveau relativement élevé du salaire minimum. Enfin, pour lutter contre le dualisme croissant du marché du travail, on devra assouplir la législation sur la protection de l'emploi pour les contrats de travail réguliers une fois la crise économique dissipée, et il convient aussi de supprimer progressivement le traitement préférentiel appliqué à l'emploi des étudiants. Ce Document de travail se rapporte à l'Étude économique de l'OCDE de la Slovénie 2009 (www.oecd.org/eco/études/slovénie).

Classification JEL : J21; J22; J32; J26.

Mots clés: Slovénie ; taux d'activité ; dualisme du marché du travail.

\section{Copyright OECD 2009}

Application for permission to reproduce or translate all, or part of, this material should be made to: Head of Publications Service, OECD, 2 rue André-Pascal, 75775 Paris Cedex 16, France. 


\section{TABLE OF CONTENTS}

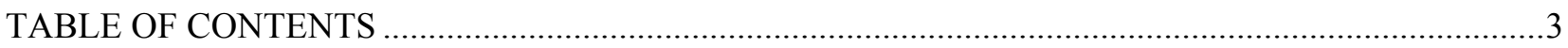

IMPROVING THE FUNCTIONING OF THE SLOVENIAN LABOUR MARKET...................................5

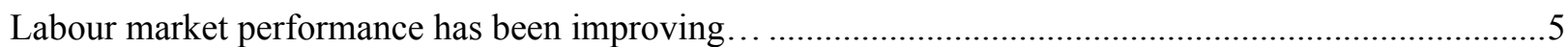

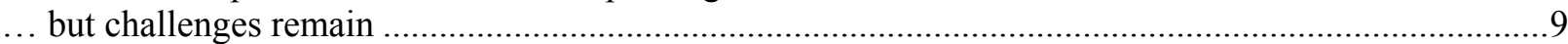

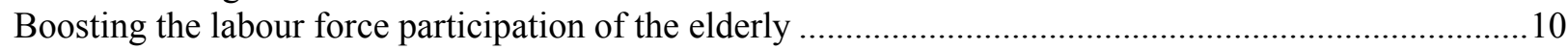

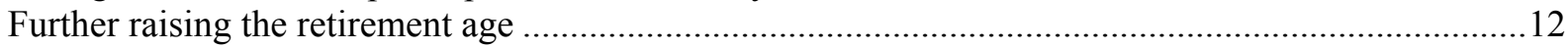

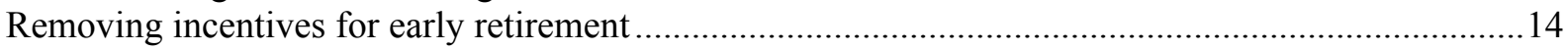

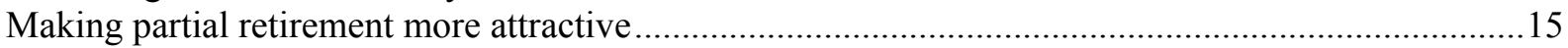

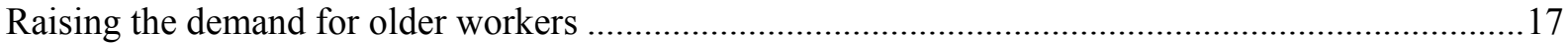

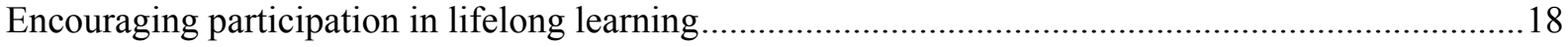

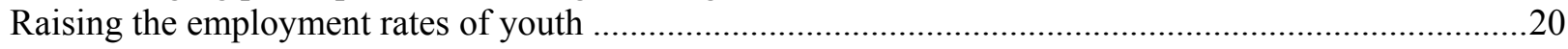

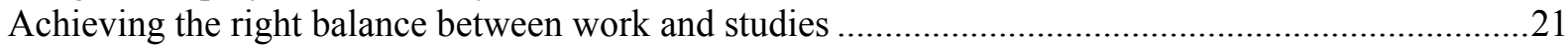

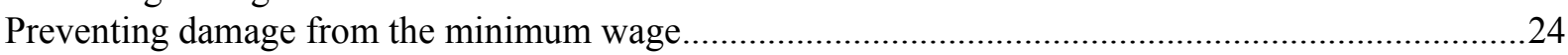

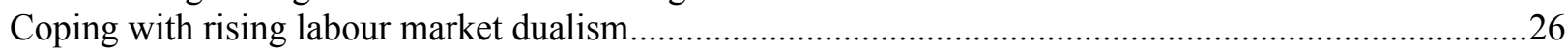

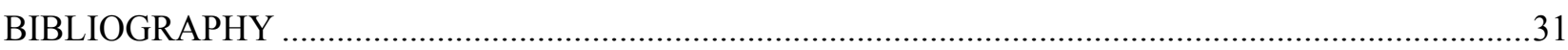

ANNEX A1. ESTIMATING A TIME-VARYING NAIRU BY MEANS OF THE KALMAN FILTER..33

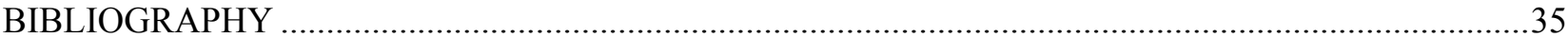

\section{Tables}

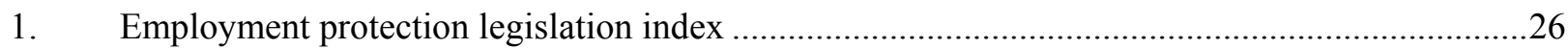

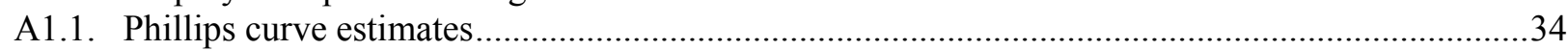

\section{Figures}

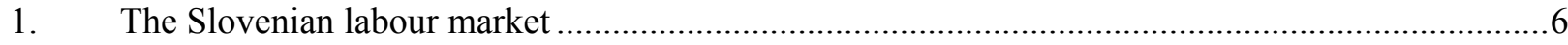

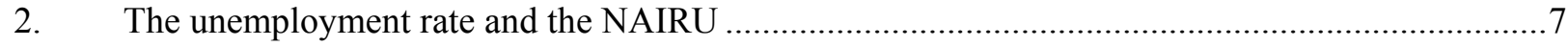

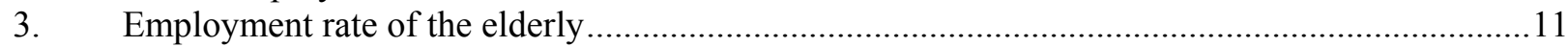

4. Average effective age of retirement versus the official age ........................................................11

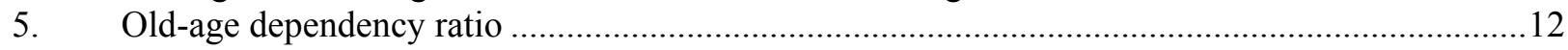

6. Life expectancy and retirement age in selected OECD countries ...........................................13

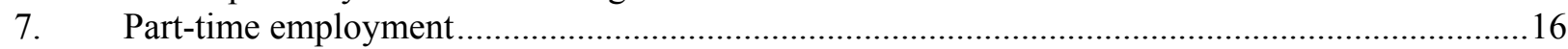

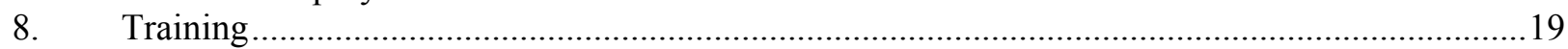

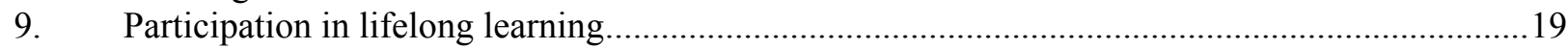

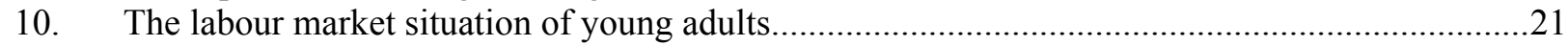

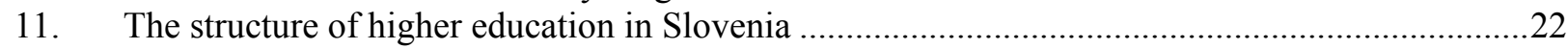

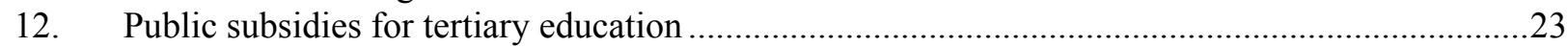




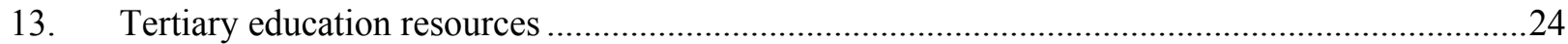

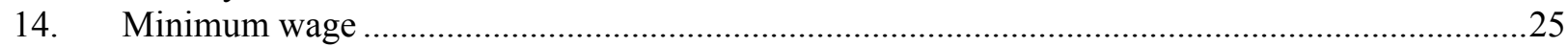

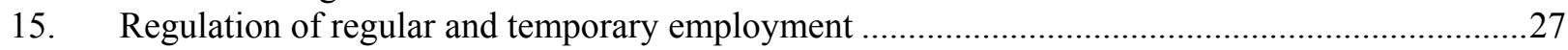

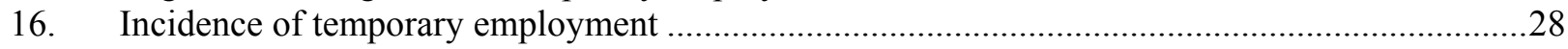

\section{Boxes}

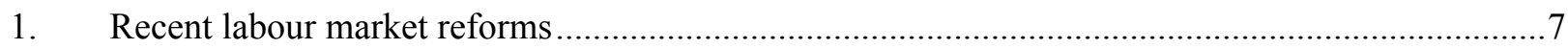

2. The German subsidy scheme for shorter working hours........................................................10

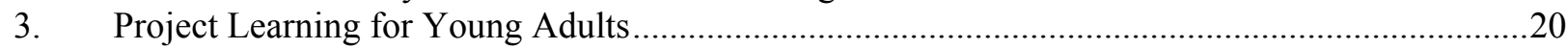

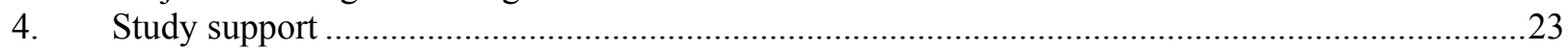

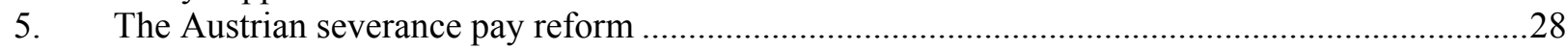

6. Main recommendations to improve the functioning of the labour market.....................................29 
ECO/WKP(2009)60

\title{
IMPROVING THE FUNCTIONING OF THE SLOVENIAN LABOUR MARKET
}

\author{
by \\ Isabell Koske ${ }^{1}$
}

\section{Labour market performance has been improving...}

1. Along with the strong economic growth of recent years, labour market performance has improved markedly. Between 2003 and mid-2008 the employment rate increased by 5 percentage points to around $69 \%$. With labour force participation roughly constant throughout this period the rise in aggregate employment was mainly reflected in a fall in the unemployment rate which came down from $6.7 \%$ in 2003 to $4.2 \%$ in mid-2008. In 2007 Slovenia had the lowest unemployment among the Central and East European OECD countries (Figure 1, panel A). Estimates of the NAIRU - the rate of unemployment consistent with non-accelerating inflation - suggest that the fall in unemployment was mostly cyclical with the unemployment rate falling substantially below the estimated level of the NAIRU, especially in 2007 and 2008 (Figure 2 and Annex 1). This is in line with relatively high wage growth in these years. ${ }^{2}$ Nonetheless, the beneficial effects of the economic upswing seem to have been reinforced by important structural reforms (Box 1) that have been associated with a gradual decline in the NAIRU over time.

2. Although aggregate employment is close to the OECD average of $70 \%,{ }^{3}$ large disparities remain across different age groups and across groups of different educational attainment. While employment rates are around the OECD average for men aged 30 to 49 and well above the OECD average for women in that age group, they are very low for the elderly, reflecting low participation rates (Figure 1, panel B). In 2007 only $47 \%$ of those aged 55 to 59 and only $17 \%$ of those aged 60 to 64 participated in the labour force compared with OECD averages of respectively $66 \%$ and $43 \%$. The low participation of older age cohorts is mirrored in low effective age retirement ages of around $60^{2} / 3$ years for men and $571 / 2$ years for women. ${ }^{4}$

1. Economist in the Economics Department. This Working Paper incorporates Chapter 3 of the OECD's 2009 Survey of Slovenia which was prepared under the responsibility of the Economic and Development Review Committee. The author is grateful for the valuable comments received on earlier drafts of this text from Andrew Dean, Bob Ford, Pierre Beynet and other colleagues in the Economics Department, as well as for discussions with officials from the Slovenian government. Special thanks go to Desney Erb of the OECD Economics Department for statistical assistance.

2. Private sector gross earnings rose by around $6 \frac{1}{2}$ per cent in 2007 and $81 / 2$ per cent in 2008, compared with an average of $3 \frac{1}{2}$ per cent per annum over the period 2003-06 when the unemployment rate was close to the NAIRU.

3. The relatively high participation rate is partly due to the structure of the Slovenian population with almost no foreigners and relatively few low-skilled persons. ECB (2008) argue that although the observed Slovenian participation rate is above the euro area average it would be clearly below that average if Slovenia were to have the same population composition as the euro area as a whole.

4. The numbers refer to persons who retired in 2007 under general and special regulation and are taken from the Institute of Pension and Invalidity Insurance of Slovenia (ZPIZ, 2008). 
Figure 1. The Slovenian labour market

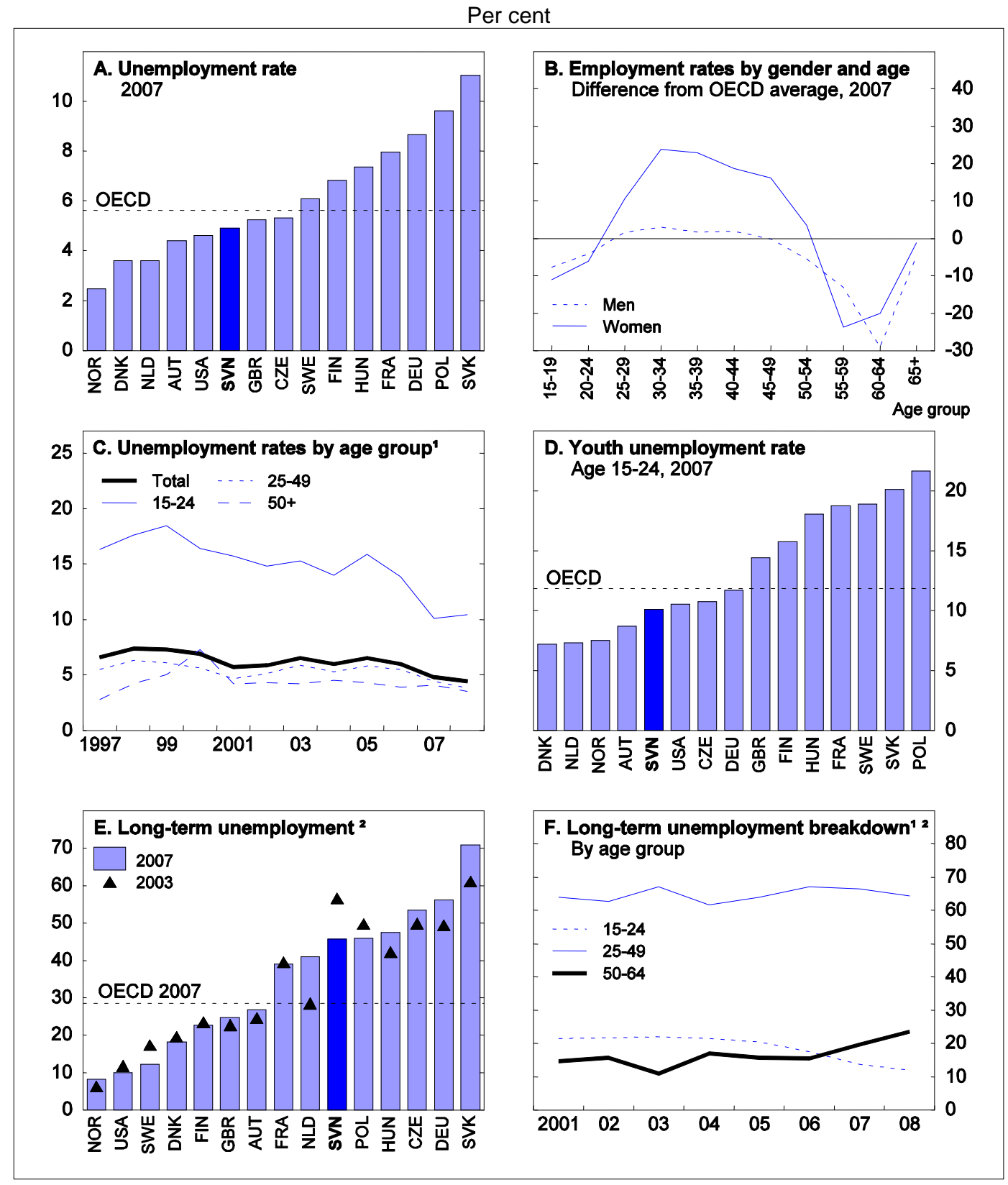

1. The reliability of results of the detailed unemployment data by age and gender may be affected by the small sample size or the sampling method used.

2. Unemployment duration of one year or longer in per cent of total unemployment.

Source: OECD (2008), OECD Employment database - online version, www.oecd.org/els/employment/data and Eurostat database (2009), Labour Force Survey, May. 
Figure 2. The unemployment rate and the NAIRU

Per cent

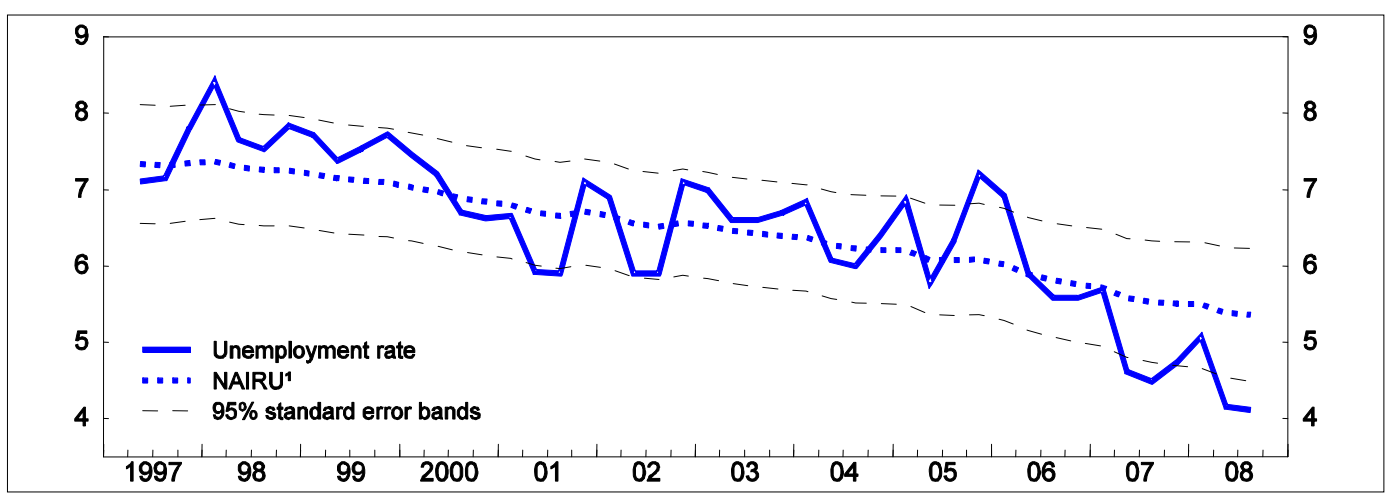

1. Non-accelerating inflation rate of unemployment.

\section{Box 1. Recent labour market reforms}

Slovenia has implemented several reforms of the labour code in recent years aimed at increasing the flexibility of its labour market. This was necessary not least to improve the country's ability to cope with asymmetric shocks in the euro area that cannot be dealt with by the common monetary policy. This box briefly outlines the main reforms that have been undertaken since 1997, when the OECD's only other Economic Survey of Slovenia was published.

\section{Regulation of employment contracts}

In 1998, amendments to the Employment and Insurance against Unemployment Act (EIUA) licensed the operation of temporary work agencies and thus contributed notably to a liberalisation of temporary employment. More flexibility in the area of regular employment was introduced by the 2003 Employment Relationships Act (ERA) which shortened notice periods, reduced the levels of severance pay and relaxed regulations on collective dismissals, but put additional restrictions on temporary work. More recently, the establishment of specialised temporary work agencies was made easier through amendments to the EIUA adopted in 2006. ${ }^{1}$ The 2007 amendments to the ERA expanded the possibilities for fixed-term contracts, ${ }^{2}$ exempted contracts for project work from the two-year time limit for temporary employment, and facilitated the termination of regular work contracts by further shortening notice periods in case of termination due to business reasons (to 30 days for less than 5 years of tenure, 45 days for at least 5 years of tenure, 60 days for at least 15 years of tenure and 120 days for at least 25 years of tenure) and exempting employers from the obligation to pay severance pay if the employer or the Employment Service offers the employee an employment contract with another employer during the notice period and the employee concludes this contract. The amount of severance pay remained unchanged at one-fifth of the average monthly wage during the last three months before the termination of the contract for each year of employment, if the worker has been employed for more than one and up to five years (one-fourth if employed for 5 to 15 years and one-third if employed for more than 15 years).

\section{Duration and level of unemployment benefits}

The amended EIUA adopted in 1998 cut the potential period of entitlement to unemployment benefits for some groups of the unemployed (to 3 months for insurance up to 5 years, to 6 months for insurance of 5 to 15 years, to 9 months for insurance of 15 to 25 years and to 12 months [18 months if the insured person is older than 50 years and 24 months if the person is older than 55 years] for insurance of over 25 years). ${ }^{3}$ In 2006 , stricter rules were introduced regarding the obligations of unemployed: they are obliged to actively search for employment and after three (six) months of unemployment they have to accept a job offer from the Employment Service for which the education is one level (two levels) below the education level of the unemployed person. If the unemployed person does not comply with these rules the cash benefit is cut in half for a period of two months. The level of unemployment benefits has not changed since the last Economic Survey and amounts to $70 \%$ of the average monthly salary received in the 12 months prior to unemployment for the first three months and to $60 \%$ in the subsequent months. The minimum (maximum) benefit is equal to 0.46 (1.37) times the minimum wage. Unemployment assistance was abolished in 2006. Instead, the unemployed can get means-tested social assistance after the expiration of unemployment benefits. 


\section{Labour taxation}

The rates of payroll tax were gradually reduced between 2006 and 2008 and the tax was completely phased out in January 2009, considerably reducing unit labour costs. Furthermore, reforms of the personal income tax led to a reduction in the number and level of tax rates. In 2005, the number of tax rates was cut from six (from $17 \%$ to $50 \%$ ) to five (from $16 \%$ to $50 \%$ ) and in 2007 , the number was further reduced to three (16\%, $27 \%$ and $41 \%$ ). In 2008 , the level of general and special personal income tax allowances was raised, lowering the tax burden, in particular for low income earners, and special allowances were reduced and simplified.

\section{Wage bargaining}

In 2006, the Collective Agreements Act came into force and introduced significant changes to the system of collective bargaining. The Act regulates the parties, scope and hierarchy of collective agreements, and the procedure of conclusion and termination of the collective agreement as well as its validity. The Act does not provide for the mandatory conclusion of collective agreements or the mandatory content, nor does it determine the types of collective agreements and the level of their conclusion. The main novelties introduced by the Act include the principle of voluntary conclusion, the possibility of subsequent accession to concluded collective agreements, the restriction of the validity of collective agreements to the parties that concluded it or their members, and the regulation that the collective agreement that is most favourable to workers should apply if an employer is bound by more than one collective agreement of the same type. Wages are limited downwards by the Minimum Wage Act, introduced in 2006. According to the Act the minimum wage is determined once a year by the Minister of Labour based on the forecast of consumer price inflation, after consulting the social partners.

\section{Active labour market policy}

Slovenia's expenditure on active labour market policies (ALMP) amounted to around $0.22 \%$ of gross domestic product (GDP) in 2008, part of which is financed by the European Social Fund. At the end of 2006, new guidelines for ALMP were adopted within the Active Labour Market Policy Programme for the period 2007-13. The programme envisages measures in four areas: i) counselling and assistance for employment; ii) training and education; iii) promotion of employment and self-employment; and iv) programmes for increasing social inclusion. The programme is complemented by action plans which are confirmed by the government for each budget period. New ALMP envisaged for 2009 include a subsidy programme to promote employment of young people with tertiary education and of older and long-term unemployed persons; the promotion of part-time work; and education and training programmes for unemployed who wish to become self-employed and for employees of micro and small firms and of firms with subsidised full-time employment.

\section{Organisation of working time}

Some measures have been taken to facilitate the reconciliation of work and private life, for example by granting parents the right to work fewer hours. The 2007 amendments to the ERA introduced possibilities for longer overtime work and, so as to make part-time work more attractive to employers, defined the principle of proportionality of rights of part-time employees with respect to the number of working hours. The amended Prevention of Illegal Work and Employment Act opened employment possibilities for short-term and small work by considering it as declared work. ${ }^{4}$

\section{Migration}

In 2001, a new Employment and Work of Aliens Act came into force, providing for a comprehensive regulation of all forms of work by foreigners (excluding citizens of all EU member countries) in a single Act. The Act specifies different types of work permits ${ }^{5}$ according to the aim and the duration of employment and regulates the number of foreigners allowed to enter the Slovenian labour market (the annual quota is set by the government, though it may not exceed $5 \%$ of the actively working population). In 2005 , conditions were tightened for self-employed foreigners (the requirement of one year of prior residence in Slovenia was introduced) whereas they were relaxed for seasonal workers. In 2007, the Act was amended to simplify procedures for workers from occupations facing labour shortages.

1. Such agencies can now acquire the right to provide temporary work only by entry in the registry of agencies providing temporary work and do not have to conclude a concession contract as other employment agencies have to do.

2. In particular, the amendments expanded the possibilities for temporary work contracts to cases where none of the applicants fulfils the required conditions for the job, employment of managers and employment on projects.

3. The cut in benefit duration had a sizable positive effect on the exit rate out of unemployment at all lengths of the unemployment benefit duration (Ours, J.C. van and M. Vodopivec [2006], "How Shortening the Potential Duration of Unemployment Benefits Affects the Duration of Unemployment: Evidence from a Natural Experiment", Journal of Labor Economics, Vol. 24, No. 2, University of Chicago Press, Chicago), though it did not reduce job match quality (Ours, J.C. van and M. Vodopivec [2008], "Does Reducing Unemployment Insurance Generosity Reduce Job Match Quality", Journal of Public Economics, Vol. 92, No. 3-4, Elsevier BV, Amsterdam). 
4. Short-term work is unpaid work in micro firms or private institutions by the spouse of the owner or a person to whom he/she is related to in the first degree, and which lasts 40 hours a month at the most. Small work lasts not more than 20 hours a week and not more than 40 hours a month, while payment does not exceed $50 \%$ of the minimum wage, and is carried out by a person who is not in full-time employment, who does not pursue an independent activity and who does not receive a pension.

5. Three different types of work permits exist: personal work permits, employment permits and permits for work. A personal work permit is issued on the application of a foreigner who has a temporary or permanent residence permit and who has lived in Slovenia for at least one year, and grants free access to the Slovenian labour market. An employment permit is issued upon the request of an employer, provided that he meets all necessary conditions, including the provision that hiring a foreigner does not adversely affect the domestic unemployment situation. A permit for work allows a foreigner to work in Slovenia for a limited period of time defined in advance based on the purpose for which the permit is issued (e.g. seasonal work, managerial work).

3. The employment rates of those aged 15 to 24 are also lower than in the average OECD country (Figure 1, panel B), reflecting a high participation of youth in education and a longer duration of education. The unemployment rate of those aged 15 to 24 has fallen considerably in the past years, coming down from $15 \%$ in 2003 to below $10 \%$ in 2008 (Figure 1, panel C). Particularly lower-skilled youth (without upper secondary education) benefited from this development. Favourable economic conditions as well as active policy measures to integrate the youth into the labour market are the main factors behind the decline in youth unemployment. In addition, the fact that smaller generations of young people are entering the labour market due to the ageing process may have contributed to this development. While unemployment is still much more prevalent among the youth than among other age groups, Slovenia performs better than many other OECD economies (Figure 1, panel D).

4. Along with the decline in overall unemployment, the pool of long-term unemployed has also been reduced in recent years. Past labour market reforms such as the tightening of eligibility criteria for unemployment benefits and active labour market policies (ALMP) aimed at upgrading the skills of those unemployed, who are unable to return directly from unemployment to a new job, are likely to have contributed to this development (Box 1). Nonetheless, the share of long-term unemployed in total unemployed remains well above the OECD average (Figure 1, panel E). As older workers benefited less from the recent fall in long-term unemployment than other groups, they now account for a higher share of long-term unemployed than before the economic upswing (Figure 1, panel F).

\section{... but challenges remain}

5. The substantial and welcome progress in improving labour market outcomes notwithstanding, challenges remain in specific areas. In the short term the main challenge will be to cope with rising unemployment due to the global economic crisis. The government has adopted a number of measures to safeguard jobs and contain the rise in unemployment within the fiscal package adopted in February 2009. Whilst such initiatives are vital under current circumstances, it is important that they are well designed and do not harm economic growth in the long run. In this respect, the subsidy scheme for shorter working hours should be phased out once the crisis dissipates. In the meantime, eligibility should be temporary in nature as is the case in several other OECD countries such as Germany (Box 2). Moreover, any measures that are detrimental to the functioning of the labour market should be avoided. tightening the rules for immigrant workers during the crisis in order to maintain jobs for Slovenian citizens would be the wrong way to go as immigrant workers are needed in the longer run to address skill mismatches in the domestic labour market.

6. It is also important to look beyond the short-term horizon and reflect on the structural problems of the labour market. As stressed by Høj et al. (2006), structural reforms are sometimes easier to implement in times of economic crises because bad economic conditions make it clearer that existing policies are no longer sustainable, either for individual citizens or for the economy. On the other hand, the political opposition to reforms in certain specific labour market areas (for example, employment protection legislation) is likely to be stronger during economic downturns as workers are already suffering from high unemployment. It therefore seems expedient to proceed rapidly with reforms that are not costly under 
current circumstances but have beneficial effects in the long run (such as a reform of the pension system) while delaying reforms that face strong opposition due to the crisis until the next economic upswing. On the whole, three main areas stand out where further reform is needed (by the importance of issues and hence suggested priority for policy makers):

- Labour force participation rates among the elderly are very low by international standards.

- Despite recent increases, the employment rates of younger age cohorts remain relatively low, partly reflecting a long time in completing education.

- The share of temporary employment has been rising quickly, especially among youth, which risks creating a dual labour market.

\section{Box 2. The German subsidy scheme for shorter working hours}

The subsidy scheme for shorter working hours is meant to reduce the labour costs of companies that are in temporary distress. Companies are eligible for the subsidy if they face a major drop in orders due to economic reasons or extraordinary events, provided the drop in orders is temporary in nature. More than one-third of the employees must lose at least $10 \%$ of their gross wage for the company to be eligible, though this condition is suspended from February 2009 to December 2010 (instead, the subsidy can only be paid to employees who lose more than 10\% of their gross wage). The scheme can only be introduced if it is agreed in a collective agreement, a company agreement or the working contract of the individual employee. If a work council is active in the company it also has to agree to the implementation of the scheme. Employees participating in the scheme have to accept a cut in their monthly income as the State only pays $60 \%$ of the forgone net wage (67\% if the employee has children). ${ }^{*}$ Contributions to pension, health and care insurance are paid on $80 \%$ of the foregone income with the employers paying all of it, i.e. not only their share but also the employees' share (part of the payments are currently refunded as part of the government's fiscal stimulus package). The maximum duration of eligibility is generally limited to 6 months, though it has recently been extended to 24 months for all employees that become eligible before the end of 2009. Since end 2008, the scheme may also be used for workers of temporary work agencies.

Some collective agreements stipulate that the benefits paid by the State are to be extended by the employer.

\section{Boosting the labour force participation of the elderly}

7. The employment rates of older persons have increased markedly over the past decade. The increase was particularly strong for persons aged 55 to 59, owing to the effects of the 1999 pension reform as well as to demographic effects as the early-retirement generation from the early 1990s is leaving this age group. Between 1997 and 2008, the employment rate of this age group rose by around 17\%, reaching slightly more than $45 \%$ in the third quarter of 2008 . However, despite this progress the employment rate is still the third-lowest in the OECD (Figure 3). The employment rate of persons aged 60 to 64 is also amongst the lowest in the OECD and, due to rising employment rates in many other OECD countries, has even fallen further behind the OECD average in recent years. The low employment rates of older persons are mirrored by a low effective retirement age (Figure 4). Men retire about three years earlier in Slovenia than in the average OECD country whilst for women the difference is as much as five years. ${ }^{5}$ The low effective retirement age, together with rapid population ageing (Figure 5), puts pressure on the growth of public expenditure for old-age pensions and at the same time limits the growth potential of the economy through a shrinking labour force. To avoid these negative effects it is essential that steps are taken to boost the labour force participation of the elderly.

5. The effective retirement ages shown in Figure 3.4 are estimated based on Labour Force Survey (LFS) data to be comparable across countries. The figures for Slovenia are somewhat higher than those published by the Institute of Pension and Invalidity Insurance of Slovenia (ZPIZ, 2008) which are based on the actual age of the persons applying for pension benefits in a given year. A possible explanation for the difference is that some persons are officially retired but continue working in the informal sector. As the LFS considers these persons as employed, such informal employment pushes up the estimated effective retirement age. 
Figure 3. Employment rate of the elderly

Per cent

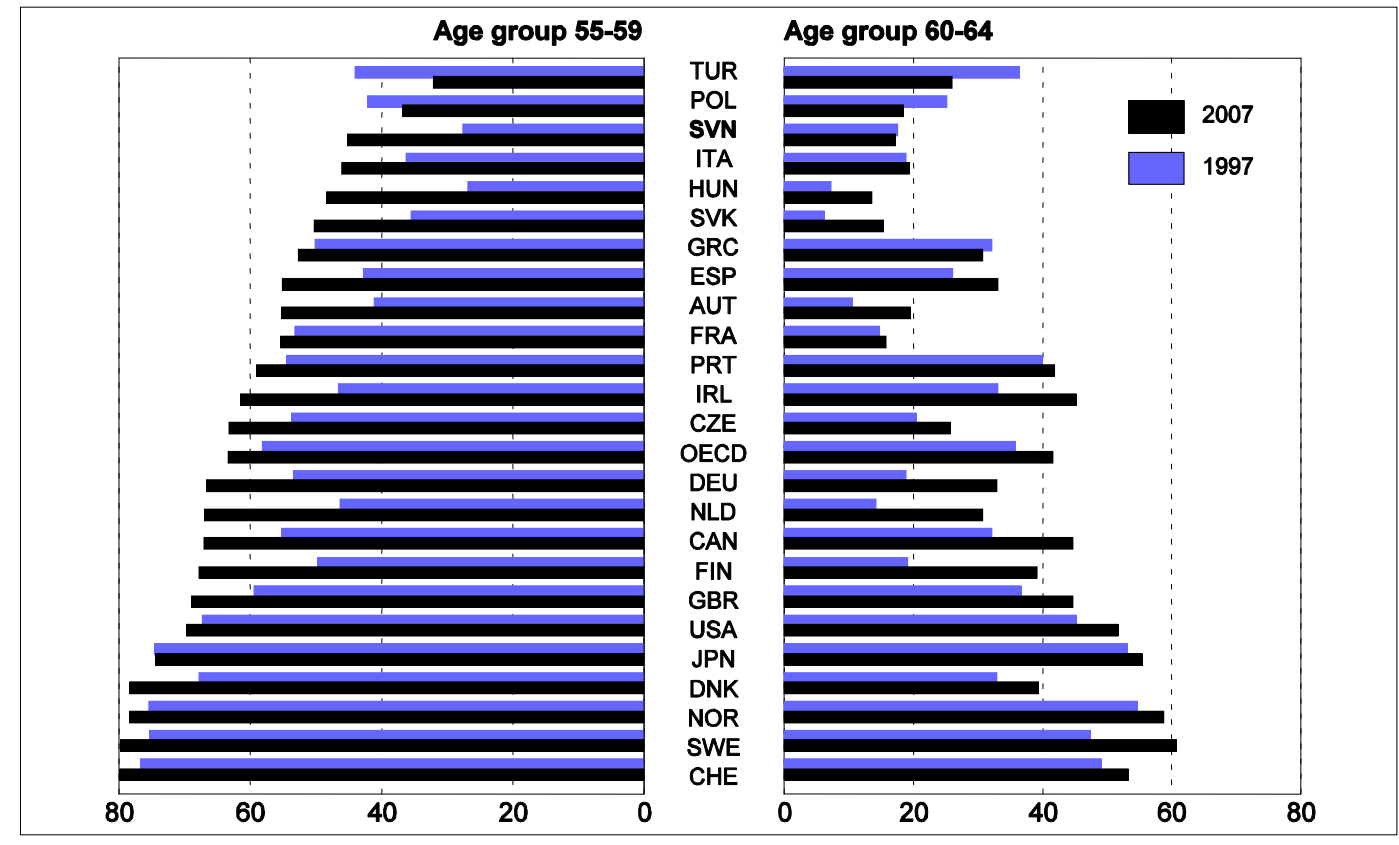

Source: OECD (2008), OECD Employment database - online version, www.oecd.org/els/employment/data.

Figure 4. Average effective age of retirement versus the official age ${ }^{1}$

2002-07

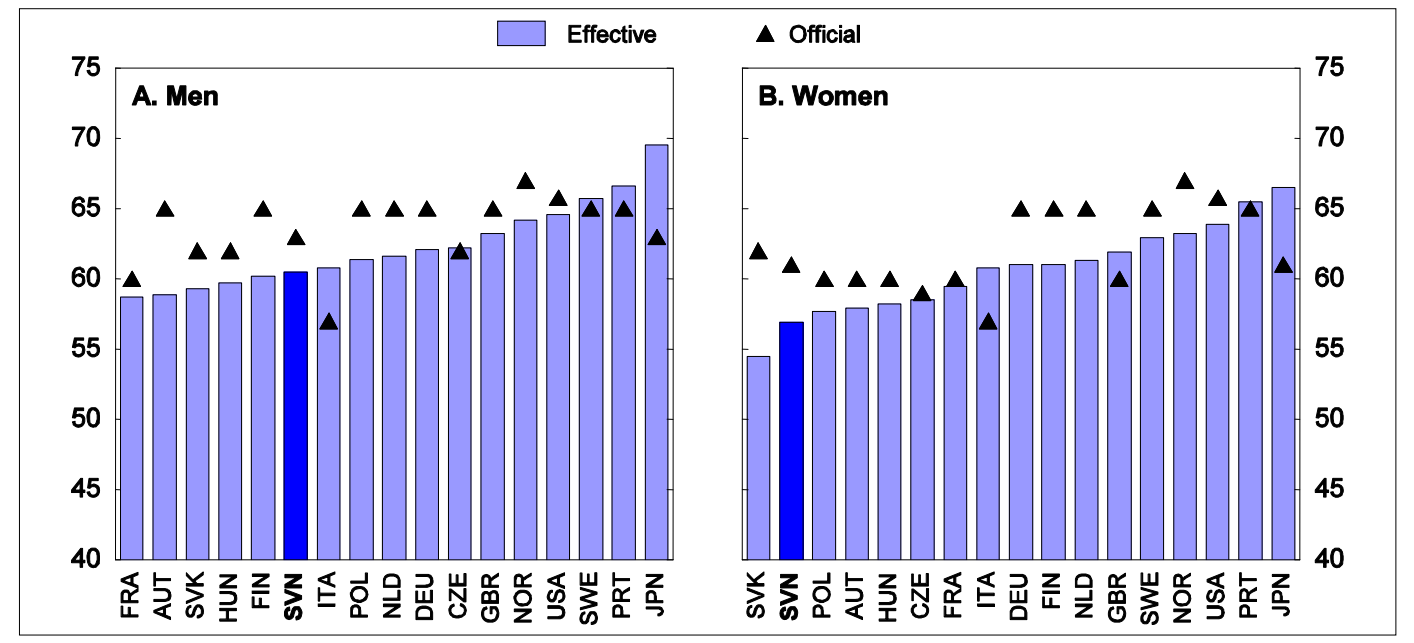

1. The average effective age of retirement is defined as the average age of exit from the labour force during a 5-year period. Labour force (net) exits are estimated by taking the difference in the participation rate for each 5-year age group (40 and over) at the beginning of the period and the rate for the corresponding age group aged 5-years older at the end of the period. The official age corresponds to the age at which a pension can be received irrespective of whether a worker has a long insurance record of years of contributions. For Italy, workers can retire at age 57 (56 for manual workers) with 35 years of contributions. For Slovenia, the official retirement age of 61 years for women will be reached in 2023 and for the Slovak Republic, the official retirement age of 62 years for women will be reached in 2015.

Source: OECD (2009), Ageing and Employment Policies - Statistics on average effective age of retirement, available at www.oecd.org/document/47/0,3343,en_2649_34747_39371887_1_1_1_1,00.html. 
Figure 5. Old-age dependency ratio ${ }^{1}$

Population aged $65+$ as per cent of population aged 15-64

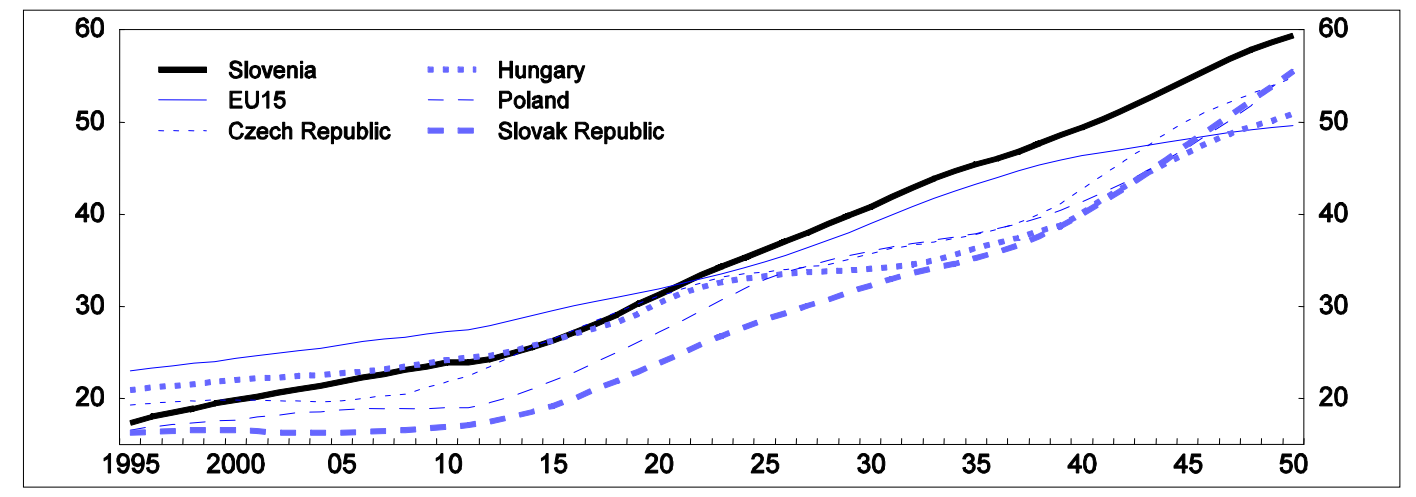

1. Using population projections from the convergence year in 2150 scenario, population at 1 January.

Source: Eurostat database (2009), Population and Social Conditions, May.

8. Work and retirement decisions are highly complex and depend on a range of institutional settings as well as the socio-demographic characteristics of the individual (OECD, 2006a; Vodopivec and Dolenc, 2009). First, so-called "pull" factors, associated primarily with financial incentives embedded in public pension and early retirement schemes, are "pulling" older workers into retirement and thus play an important role in determining retirement decisions (e.g. Burniaux et al., 2003; Duval, 2003; Burtless, 2009). The decisions will be influenced by the age at which benefits can first be claimed, the generosity of replacement rates and the accessibility of informal paths to early retirement through unemployment, disability and long-term sickness insurance programmes. Second, so-called "push" factors, which determine the available set of job opportunities open to older workers, are "pushing" workers into retirement. The job opportunities depend for example on the age profile of labour costs relative to productivity, employers' perception about the capacities of older workers, and the strictness of employment protection legislation (EPL). In addition, inflexible working time arrangement might be pushing workers into early retirement (e.g. Gustman and Steinmeier, 2004).

9. Past reforms of the labour code as well as the pension and education system have influenced these push and pull factors in the right direction, leading to a significant improvement in both work incentives and employment opportunities of older people. Examples include the gradual increase in the statutory retirement age, the introduction of ALMP tailored specifically to the needs of the elderly such as tax reliefs and exemptions from social security contributions for employers who hire older persons, and the launch of a wide range of adult education programmes. However, the recent progress notwithstanding, more needs to be done to encourage the elderly to remain active. In particular, retirement needs to be made financially less attractive for older persons by further raising the statutory retirement age and adjusting the financial incentives for early/late retirement, and the employment prospects of the elderly have to be improved to ensure that those wishing to work longer also find appropriate jobs.

\section{Further raising the retirement age}

10. Although the retirement age has already been raised by the pension reform adopted in 1999 there is room for a further increase. The retirement age (the age at which persons can retire once they have completed a pension qualifying period of 20 years) has been raised from 58 years to 63 years for men and from 53 years to 61 years for women. While the increase was implemented rather quickly for men at a rate 
of 6 months per year, the increase proceeds at just 4 months per year for women. ${ }^{6}$ This implies that the envisaged retirement age of 61 years will not be reached before 2023. The age limits for retirement with a pension qualifying period of respectively 38 years ( 58 years of age) and 15 years ( 65 years of age) are also raised by a mere 4 months per year. Several countries from Central and Eastern Europe, that had similarly low retirement ages for women before they reformed their pension systems, implemented the changes at a much faster pace. For example, Bulgaria, Estonia, Hungary and Latvia opted for an increase of 6 months per year (12 months every second year in the case of Hungary) and in the Slovak Republic the retirement age is even raised at a rate of 9 months per year. In light of the negative effects of the rapid ageing of the Slovenian population on public finances, as well as potential economic growth, the increase in the pensionable age for women should be phased-in faster.

11. Even after the 1999 pension reform is fully phased-in, the pensionable age is low by OECD standards (Figure 6). The majority of OECD countries currently have a retirement age of 65 years for both genders and many of them are planning further increases along with gains in life expectancy. As life expectancy in Slovenia is similar to other OECD countries, the lower retirement age implies a higher life expectancy at retirement (particularly for women), putting strong pressure on pension costs on the one hand and depriving the labour market of valuable resources on the other. The authorities should therefore further increase the pensionable age for both genders. Once the increase has been phased-in and life expectancy at the full pensionable age has reached a suitable level, additional increases in the pensionable age should be linked to gains in life expectancy. The length of the pension qualifying period necessary to retire at the minimum pensionable age should be raised accordingly. Moreover, the conditions for women should be lined up over time with those for men.

\section{Figure 6. Life expectancy and retirement age in selected OECD countries}

Years, 2006

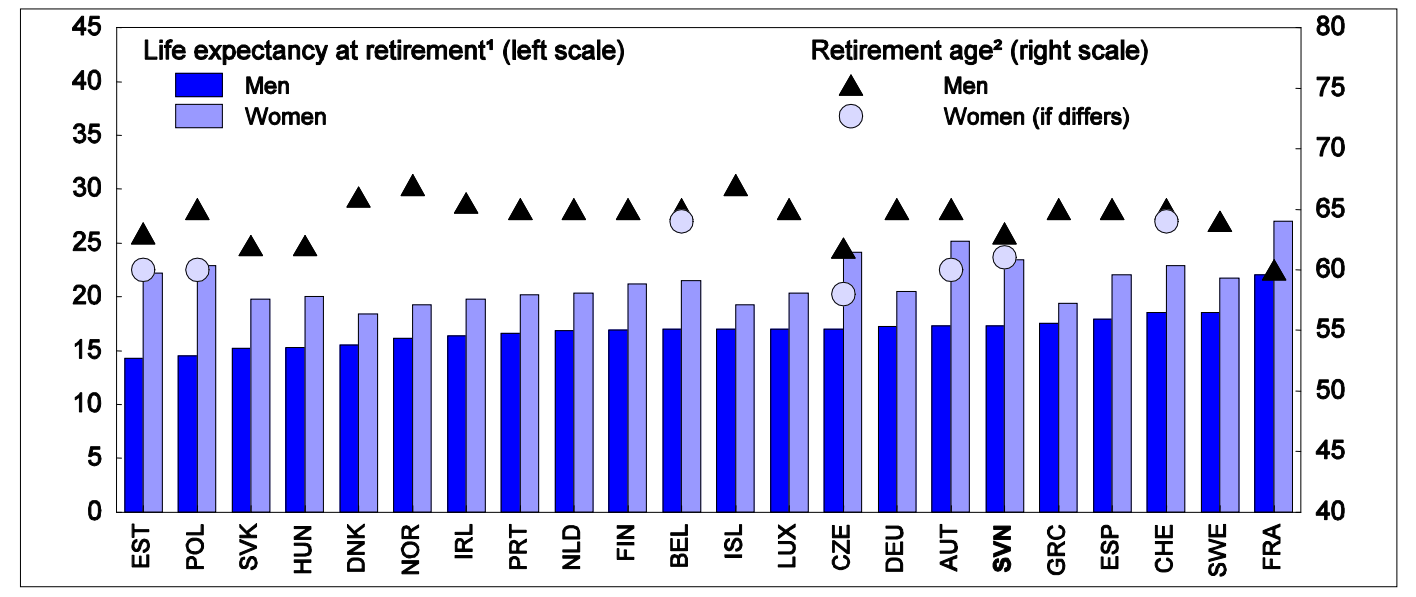

1. The mean number of years still to be lived by a person, if subjected throughout the rest of his or her life to the current mortality conditions.

2. Legal retirement age for a standard pension. Where the retirement age is variable (e.g. depending on date of birth, number of children raised, etc.), an average has been used. For the Slovak Republic, the retirement age of 62 will be reached in 2015 and for Slovenia, the retirement age of 61 for women will be reached in 2023.

Source: Eurostat database (2009), Population and social conditions, January; and European Commission, MISSOC Tables 2007, available at $h$ ttp://ec.europa.eu/employment_social/spsi/missoc_tables_en.htm.

6. The very gradual increase in the retirement age for women is typical of Slovenia's consensus based policy approach which requires the agreement of the social partners on any legislative changes within the Economic and Social Council. 


\section{Removing incentives for early retirement}

12. A major novelty of the 1999 Pension and Disability Insurance Act (PDIA) was the introduction of a comprehensive bonus/penalty system to reward deferral of retirement beyond the pensionable age and penalise retirement prior to that age. However, the size of the bonuses and penalties appears relatively small and might not provide sufficient incentives for remaining active. ${ }^{7}$ In addition, the new Act provides several possibilities for individuals to retire prior to the pensionable age without being subject to a penalty. First, the pensionable age can be reduced progressively for persons with children (by 8 months for one child, by 20 months for two, by 36 months for three and by another 20 months for each additional child). ${ }^{8}$ Second, for women who subscribe to compulsory pension insurance prior to the age of 18 , the pensionable age is lowered by the duration of insurance prior to that age. ${ }^{9}$ Third, insured persons can retire before the full pensionable age (provided they have completed a pension qualifying period of 20 years) under special conditions such as long-term unemployment, redundancy programmes, programmes allowing the employer to replace the insured person by a younger unemployed person, or the bankruptcy of the employer.

13. Such options for early retirement considerably reduce the actual age at which persons retire. Estimates of the median retirement age for the period 2002-07 based on Labour Force Survey data indicate that half of all men (women) retired before the age of 56.3 (52.5), which is markedly below the full pensionable age prevailing at that time. From a labour supply perspective, there is thus a large pool of still relatively young persons whose human capital is lost due to very early retirement. While it appears reasonable to allow for some flexibility in the retirement decision to be made by the individual based on personal preferences, the design of the pension system must not encourage early retirement. The authorities should therefore ensure that the penalties/bonuses for early/late retirement are actuarially neutral, so that the change in pension benefits from working one additional year is equal to the entitlement earned in that year and, conversely, retiring a year earlier reduces the pension benefit both by the entitlement that would have been earned during the year and by an amount to reflect the longer duration for which the pension must be paid. ${ }^{10}$ The upper limit on the number of additional working years beyond the statutory retirement age during which bonuses are paid (currently set at three years) should be abolished. In addition, the possibility to retire prior to the pensionable age for special reasons such as the upbringing of children, entry into compulsory insurance before the age of 18, long-term unemployment or bankruptcy of the employer should be phased out.

14. Raising the statutory retirement age and closing formal pathways to early retirement (or making them less attractive) might encourage individuals to switch to informal early retirement schemes, such as disability, long-term sickness and unemployment. Since the 1999 pension reform, the share of inactive persons aged 50 to 64 who do not seek employment due to disability or sickness has risen markedly, from $6 \%$ in 2000 to $22 \%$ in 2007 . The share has also increased for other age groups, albeit by a much smaller amount, indicating that disability and sickness benefits are increasingly used by the elderly to withdraw early from the labour force. The authorities should review the disability and long-term sickness insurance schemes to ensure that eligibility conditions are sufficiently tight and adequately monitored.

7. In 2007,829 persons claimed a higher pension due to late retirement compared with an increase in the number of total retirees by about 10000 persons.

8. The minimum (full) pensionable age may be reduced to 56 years (58 years) at most for women and to 58 years (60 years) at most for men.

9. The minimum (full) pensionable age may be reduced to 55 years (58 years) at most.

10. Queisser and Whitehouse (2006) calculate actuarial neutral bonuses/penalties for 19 OECD countries and obtain values in the range of $6 \%$ to $9 \%$. 
15. Unemployment benefits by contrast are not yet widely used for the purpose of early retirement. In mid-2008 the unemployment rate of 50-64 year-olds stood at around 31/2 per cent, more than half a percentage point below the aggregate rate. However, there is a risk that this pathway becomes more popular in the future along with further increases in the retirement age and stricter controls on disability and sickness benefit recipients. To prevent this from happening, the generosity of the scheme should be reduced further for older people. Currently, older workers with an insurance history of 15 to 25 years are eligible for benefits during respectively 18 months (if they are older than 50 years) and 24 months (if they are older than 55 years) whereas workers below the age of 50 receive benefits for 12 months. As a result, the incidence of unemployment benefits is highly skewed in favour of older workers. The authorities should reduce the length of unemployment benefit duration for long-term unemployed older workers towards the general length of 12 months, once the current economic crisis dissipates.

16. Work decisions may also be influenced by the degree to which an individual's pension benefits are linked to the entire working career in terms of length and level of earnings. If pension benefits are calculated based on a finite number of best years, older workers might be encouraged to exit from the workforce, particularly if they do not expect any further increases in earnings or have to accept earnings cuts to stay employed. Since 2008, pension benefits in Slovenia are based on the 18 best consecutive years (the assessment period had been gradually increased from 10 years in 2000 after the passage of the 1999 PDIA). The link between pension benefits and working careers could be strengthened further by basing benefits on full lifetime average earnings as is done in most OECD countries (OECD, 2007).

\section{Making partial retirement more attractive}

17. Inflexible working time arrangements may discourage older workers from continuing to work longer due to difficulties in reconciling work with family life. This may result in a cliff-edge pattern of retirement with older workers shifting instantly from working full-time to not working at all (OECD, 2006a). Such an abrupt departure from the full-time career job may actually not be the preferred path to retirement for many workers; they would prefer to gradually reduce their work commitments over a period of time. Rigidities to a gradual exit from the labour market may result, first from barriers to part-time work in general (as shown in panel A of Figure 7 those countries with a higher incidence of part-time employment tend to have higher overall labour force participation of the elderly), and second from constraints on the right to draw all or part of a pension while continuing to work at the same time. In Slovenia, individuals are not allowed to be retired and work at the same time, though it is possible to retire partially which means receiving half of one's pension and continue working half-time (or less). Yet, the possibility of partial retirement is hardly used; at the end of 2007, only 184 persons retired in such a way (IMAD, 2008a), which is less than $2 \%$ of new old-age pension recipients.

18. Restrictions on part-time work in general are unlikely to be the main explanation for the low number of partial retirees. Although the share of workers aged 50 to 64 working part-time falls short of the levels seen in most OECD countries (Figure 7, panel B) and has not increased in recent years, the number of such jobs has risen among other age groups, most notably the young (Figure 7, panel C), not least thanks to some progress in liberalizing working-time arrangements (Box 1). ${ }^{11}$ It thus seems more likely that factors related to the partial retirement scheme itself are at the root of its low popularity.

19. The rules on partial retirement are indeed such that the scheme does not appear very attractive. First, the conditions for partial retirement are very tight as it requires the fulfilment of the conditions for

11. The rise was particularly strong in 2003, which may be related to the acceleration in economic growth and, in the case of women, to the right to work reduced hours introduced by the Parental Protection and Social Benefit Act (IMAD, 2008a). Moreover, a large share of those aged 15 to 24 in part-time employment is student workers. 
full retirement and the consent of the employer. Moreover, the partial retiree is allowed to work on a halftime basis at the most and will receive one-half of the old-age pension to which he is entitled. Second, partial retirement is financially not very attractive as the pension income is taxed as regular income (although the pension already represents net income taxed through the translation of the gross pension basis to the net pension basis) and the wage income is subject to social security contributions. Whilst the contributions to pension insurance translate into a higher replacement rate upon full retirement, contributions for health and unemployment insurance act essentially as a tax since individuals who meet the criteria for retirement are not eligible for unemployment benefits and since health insurance contributions for full retirees are paid for by the Institute of Pension and Invalidity Insurance of Slovenia.

Figure 7. Part-time employment

Per cent

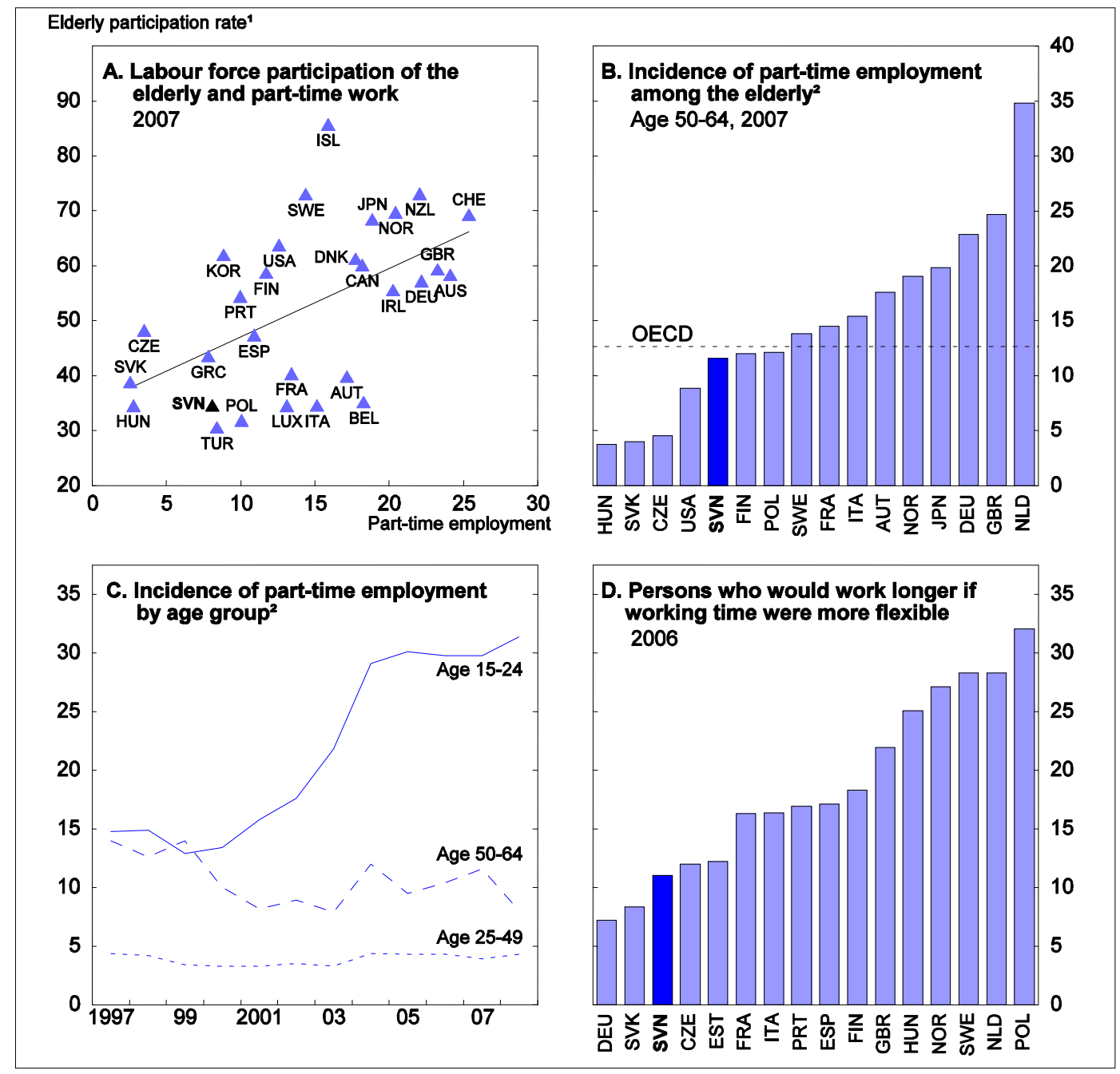

1. Age group 55-64.

2. In per cent of total employment.

Source: OECD (2008), OECD Employment database - online version, www.oecd.org/els/employment/data and Eurostat database (2009), Labour Foce Surveyr, May. 
20. Although Slovenia is likely to benefit less from a relaxation of partial retirement conditions than other OECD countries, still 11\% of employed persons stated in the 2006 Labour Force Survey that they would stay longer at work if more flexible working time arrangements were available (Figure 7, panel D). The authorities should therefore allow people to receive wage and pension income at the same time. At the very least, the rules for partial retirement should be relaxed and the tax disincentives should be phased out. In particular, there is no need to demand the consent of the employer for partial retirement, if EPL is sufficiently flexible (see below). While easing barriers to part-time work and partial retirement may lead to an increase in the participation of older people, the net impact on effective labour supply will be smaller or even negative since some workers, who prior to the change would have continued working full-time, will also reduce their hours worked (e.g. Gustman and Steinmeier, 2004).

\section{Raising the demand for older workers}

21. Whilst removing incentives for early retirement and facilitating gradual exits from the labour force will help increase the labour supply of older workers, it does not guarantee that the increase in supply is matched by a corresponding increase in demand. The demand for older workers may be limited due to negative perceptions on the side of employers about the capacities of older workers to adapt to technological or organisational changes and due to wage-setting practices that let labour costs rise more steeply with age than productivity. These issues have to be addressed in order to ensure that those people who wish to work longer also find appropriate jobs.

22. To counter negative employer attitudes, several OECD countries have launched information campaigns and introduced legislation that bans age discrimination in employment (see OECD, 2006a, Table 5.1 for an overview on the adopted measures). The two approaches are complementary: agediscrimination legislation may be less effective if not accompanied by information campaigns and guidelines to help employers implement good practices and to make older workers aware of their rights; at the same time, information campaigns and guidelines may not be very effective if not backed by sanctions for discrimination on the grounds of age (OECD, 2006a). Slovenia banned age discrimination in 2003 when the Employment Relationships Act was adopted. The legislation was amended in 2007 to define the sanctions in more detail and to shift the burden of proof towards the employer. A special information campaign to promote the employment of older workers is planned for 2009. The campaign should create awareness of the benefits of an age-diverse workforce where older workers share the benefits of their greater work experience with younger workers who in turn share their knowledge of new production techniques and ways of working with older workers. Emphasising age diversity rather than pointing out the needs of older workers reduces the risk that they become a stigmatised group. Prominent examples of information campaigns include the UK Age Positive campaign and the Finnish information campaign that was launched as part of the Finnish National Programme on Ageing Workers (see OECD, 2006a, Box 5.1 and 6.5).

23. Employers might also be reluctant to hire or retain older workers because they cost too much relative to their productivity. Some OECD countries have started to tackle this issue by moving away from seniority-based wage systems. Examples are Korea where the government has encouraged employers and trade unions to adopt a peak-wage system where wages are downward flexible after a certain age in exchange for greater job security and Sweden where wage-setting in the public sector has gradually shifted from a seniority-based system to one based much more on individual qualification and performance (OECD, 2006a). In Slovenia, the Employment Relations Act stipulates that wages must include a supplement for the number of years of service, though the size of this seniority bonus can be determined freely in collective agreements.

24. A number of OECD countries have introduced wage subsidies aimed at aligning more closely labour costs for older workers and productivity (see OECD, 2006a, Table 5.2 for an overview on wage subsidy schemes in OECD countries). This is also the approach taken by Slovenia: employers who hire an 
unemployed person older than 55 years who has been registered with the Employment Service for over 12 months or a registered unemployed person aged over 55 years with an occupation in oversupply are exempt from social security contributions. It is welcome that the wage subsidies are not granted solely on the basis of age but are more narrowly targeted at specific groups of older workers. As argued by OECD (2006a), more narrowly targeted subsidies tend be more effective than subsidies for older workers in general, as the latter may involve a substantial deadweight loss (as a large proportion of subsidised workers would have been employed even without the subsidy) and substitution effects (as subsidised jobs lead to the loss of jobs for other groups of workers ineligible for the subsidy). Moreover, subsidies granted solely on the basis of age may again lead to stigmatisation and reinforce negative attitudes on the side of employers.

25. Whilst reforming wage-setting practices to reflect individual performance and providing employment subsidies to lower the cost of employing older workers, a closer match between productivity and costs can also be achieved by helping older workers to acquire new skills and update existing ones so as to raise their productivity as discussed below.

\section{Encouraging participation in lifelong learning}

26. Due to organisational and technological change, as well as the ongoing structural shift from manufacturing to services, job requirements are constantly changing. As a result, the skills of workers risk becoming obsolete, unless they continuously acquire new skills and upgrade existing ones (Behaghel and Greenan, 2005). Participation in lifelong learning can therefore considerably enhance the employability of older workers. ${ }^{12}$ In addition, job-related training is associated with a higher wage level (Bassanini et al., 2005 ) and thus increased incentives to remain active and defer retirement. Providing workers of all ages with good access to vocational training and lifelong learning programmes can therefore help to raise the employment rates of the elderly. At the same time, workers are more likely to engage in training activities if the pension system encourages them to keep working at older ages as this increases the number of years available to recoup the returns on investment in training by both workers and employers. ${ }^{13}$ As shown in panel A of Figure 8, there is a significant positive correlation across countries between the incidence of training for older workers relative to younger ones and the average employment rate of older workers. ${ }^{14}$

27. Participation in lifelong learning activities is relatively high in Slovenia (Figure 8, panel B). Nevertheless, some scope for further improvements remains, as demonstrated by several other OECD countries such as Switzerland and the Nordic countries which have even higher participation rates. More importantly, in Slovenia, the share of the population participating in lifelong learning rapidly decreases with age which may to some extent reflect fewer expected years left in the workforce and hence fewer years to regain the returns on investment in training. While this phenomenon is common across countries, the decline is faster in Slovenia than in other OECD countries (Figure 9, panel A). The suggested further increase in the pensionable age as well as the removal of incentives for early retirement should make participation in training activities more attractive, especially at higher ages.

12. Cross country evidence for the positive employment effects of adult learning is provided by OECD (2004).

13. This is supported by Bassanini et al. (2005) reporting a negative correlation between the rate of training for older workers (relative to younger ones) and the effective tax on continued work (which is likely to be exogenous to training behaviour).

14. As discussed, the causality can run in both directions with higher participation in training raising the employment rates of the elderly and higher employment rates encouraging higher participation in training. 
Figure 8. Training ${ }^{1}$

Per cent, 2003
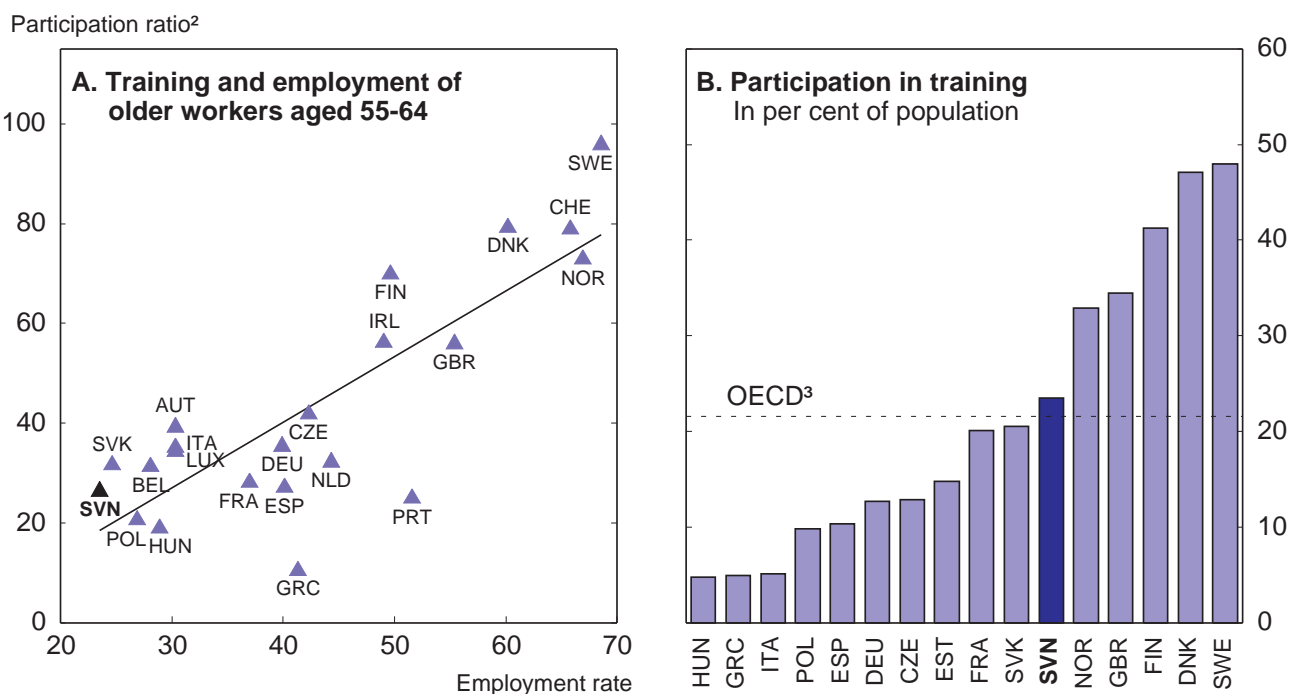

1. Non-formal education.

2. Per cent of persons participating in education, ratio of age 55-64 to age 25-34.

3. Unweighted average of data for 22 OECD countries.

Source: Eurostat database (2009), Population and Social Conditions, March.

Figure 9. Participation in lifelong learning

Per cent

\begin{tabular}{|c|c|c|c|}
\hline 40 & & & 30 \\
\hline & A. Participation in non-formal education & B. Persons who would stay longer at work & \\
\hline 30 & Dy age group, $\angle 000$ & 2006 & 25 \\
\hline 25 & & & 20 \\
\hline 20 & & & 15 \\
\hline 15 & & EU15 & 10 \\
\hline 10 & Slovenia & & 5 \\
\hline & Low retirement age countries ${ }^{2}$ & & \\
\hline & $\begin{array}{l}55-64 \\
\text { Age group }\end{array}$ & 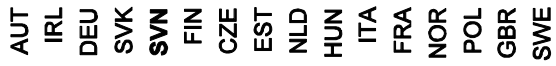 & \\
\hline
\end{tabular}

1. Unweighted average of data for 21 OECD countries

2. OECD countries with a low statutory retirement age: Belgium, Czech Republic, France, Greece, Hungary, Italy and Slovak Republic.

Source: Eurostat database (2009), Population and Social Conditions, February.

28. In addition the issue could be tackled more directly. Several initiatives have been taken in the past to promote lifelong learning in Slovenia. In 2006, the National Professional Qualifications Act was amended, introducing a system of recognition of non-formal and informal training. Under the Act, individuals can obtain a certificate demonstrating that they have the professional or vocational competencies necessary to exercise a profession based on either direct demonstration of knowledge, skills and competencies, or based on documents and other proof collected by the applicant. In 2007, the Resolution on the National Programme of Higher Education of the Republic of Slovenia 2007-10 was 
adopted, which envisages an increase in the share of population participating in lifelong learning activities and the development of programmes for employees, unemployed and inactive persons who wish to return to tertiary education. Measures in the area of lifelong learning are also envisaged in the Social Agreement for the period 2007-09 and the Operational Programme for Human Resources Development for the period 2007-13. The implementation of the Lifelong Learning Strategy adopted in 2007 is still hindered by the failure to develop an associated operational programme.

29. To further encourage the population to participate in lifelong learning, the inter-ministerial working group which was set up to discuss the implementation of the Lifelong Learning Strategy should quickly develop a plan to put the strategy into action. Given the wide range of adult education programmes currently available, it is also important to evaluate their impact on labour market outcomes. So far, such empirical assessments of specific programmes are rare. As stressed for example by Martin and Grubb (2001), the outcomes of training programmes vary considerably with programme design. In general, training that is targeted and has a strong on-the-job element appears to be the most likely to be successful. Furthermore, it is vital that the Active Ageing Strategy, which envisages specific measures to encourage the participation of older persons in lifelong learning activities, be swiftly set up and implemented.

30. The immediate impact on employment rates of any initiatives to encourage participation in training activities might be limited though. In the 2006 Labour Force Survey only 5\% of employed persons stated that they would work longer if they could update their skills (Figure 8, panel B), indicating that the lack of lifelong learning possibilities is not the main reason for withdrawing from the workforce. Nonetheless such initiatives are an important complement to the further increase in the pensionable age and the reduction of early retirement incentives. Both are likely to raise the interest of workers in lifelong learning programmes to acquire the skills needed to find employment.

\section{Raising the employment rates of youth}

31. The employment situation of youth has improved markedly in recent years with labour force participation of those aged 15 to 29 rising from $52 \%$ in 2003 to $61 \%$ in mid-2008 and unemployment falling from $12.3 \%$ to $7.4 \%$. Although the progress clearly reflects the favourable economic conditions over that period, the introduction of more flexible forms of employment as well as active labour market policies aimed at facilitating the school-to-work transition also contributed to this development. These active labour market policies include, for example, employment incentives for the young provided in the form of subsidies and tax reliefs for employers, and training and education programmes such as the Programme 10000 - Formal Education and Project Learning for Young Adults (see Box 3).

\section{Box 3. Project Learning for Young Adults}

Project Learning for Young Adults (PLYA) is a non-formal education programme for unemployed young adults aged 15 to 25 who have failed at school, have no basic vocational education and face social exclusion. The basic aim of the programme is to motivate participants to continue their formal education and acquire the knowledge and skills needed on the job-market. Participants are meant to gain positive learning experiences and to more clearly define their aspirations concerning their career and their general life. The programme has a high success rate with $60 \%$ to $70 \%$ of the participants enrolling in a suitable educational program and/or finding employment. In 2007 , the programme won the European Regional Champions Award in the area of social policy.

Participants can join PLYA any time during the school year. Participation is strictly voluntary and participants are entitled to stay in the programme for one year. The education focuses on three main areas. First, participants gain basic knowledge in a variety of fields such as mathematics, writing, communication, and natural sciences and they acquire the skills required for independent learning. Second, participants are prepared for the working life by designing a career plan, establishing links with potential employers and learning the basic components of labour legislation. Third, participants acquire socio-cultural skills such as taking responsibility for one's actions, dealing with less favourable incentives from the social environment, and using leisure time more effectively and constructively. 
Project learning is carried out in four types of project work. Individual learning projects are part of the career and individual learning plan of the student. They are derived from his/her defined personal goals such as the passing of certain exams. In optional group project work each member of the group realises his/her own learning objectives within the context of the common group project (e.g. a theatre play). The student is expected to work on the common goals of the group and the group supports the efforts of the individual student. Productive project work is concerned with the development of possibilities for the revival of old and disappearing crafts and the use of environmentfriendly technologies. Extra-curricular activities are used as a tool for raising a student's motivation and for enlarging interests within new fields in which he/she has no experience. The activities can be directly connected with a certain project or can be organised independently, just for fun or to satisfy the participant's own interest.

While participating in the programme students are guided by mentors. The mentor's sensibility for the interests and abilities of the participant is thus an important element of the programme's success. Participants actively participate in the implementation of the programme by choosing the theme of the project, the methods and procedures, which helps to increase their motivation. Every student sets up an individual learning plan that has to be realised during the programme. This plan is the foundation for the selection of activities in the programme and is also used to evaluate the student's progress according to the goals set at the beginning.

32. The recent progress notwithstanding, several problems remain that need to be addressed. First, youth labour force participation is still below the OECD average (Figure 10, panel A), reflecting a relatively long duration of initial education. Consistent with this, much of the increase in participation seen in the age group 20 to 29 is due to a rising number of student workers who are not in regular employment. Second, unemployment is still more prevalent among youth than among other age groups. Particularly youth without upper secondary education face considerable difficulties in finding employment (Figure 10, panel B). One possible reason is the high minimum wage which might hurt the young disproportionately as they tend to be less productive than other workers due to the lack of experience.

\section{Figure 10. The labour market situation of young adults}

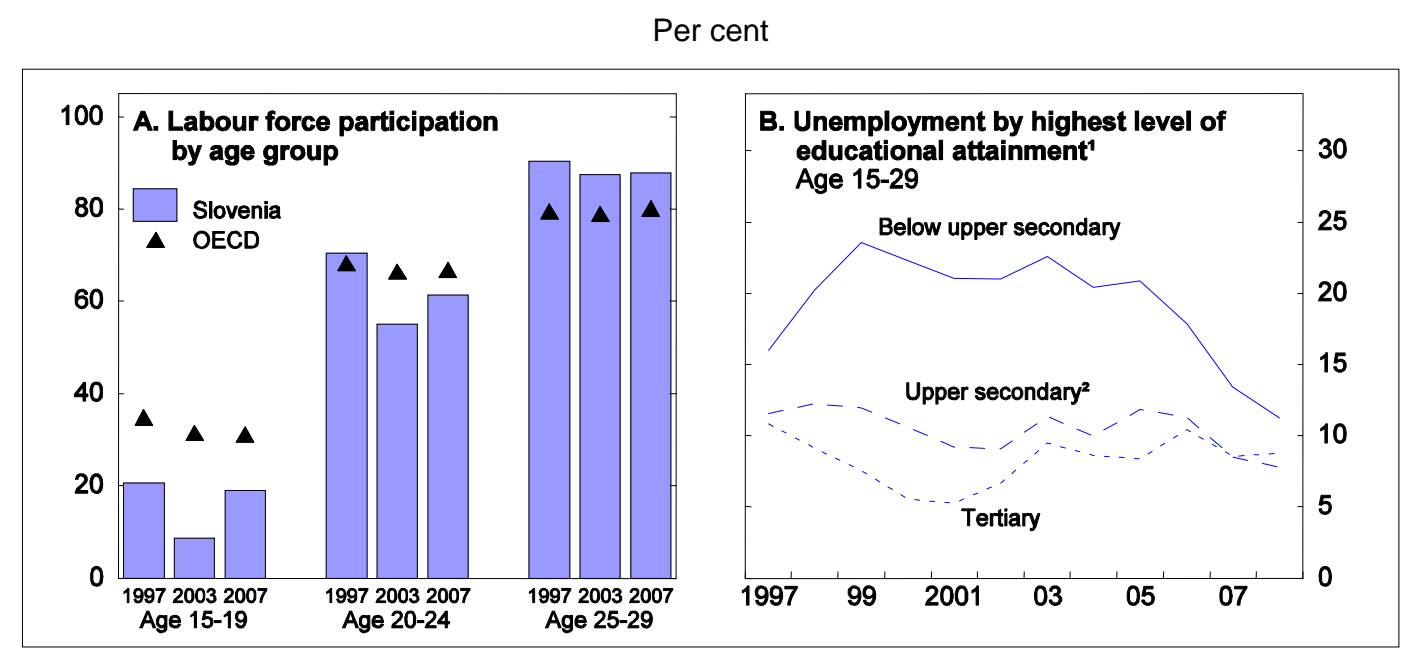

1. The reliability of results of the detailed data by age may be affected by the small sample size or the sampling method used.

2. Includes post secondary non-tertiary education.

Source: OECD (2008), OECD Employment database - online version, www.oecd.org/els/employment/data and Eurostat database (2009), Labour Force Survey, May.

\section{Achieving the right balance between work and studies}

33. The demand for tertiary education has expanded rapidly in the last decade with a rising number of school leavers wishing to continue education before entering the labour market. In 2006, one-third of 20-29 year-olds was enrolled in education compared with one-fourth in the average OECD country (OECD, 2008). As longer periods in full time education should filter through to workforce skills and 
growth potential, the increase in the number of tertiary students is a positive feature provided the right skills are acquired at the right pace. However, the average duration of tertiary studies is rather long in Slovenia. In the academic year 2006-07, students in higher professional programmes finished their studies on average in 5.4 years and students in university programmes needed 6.9 years.

34. One reason for the relatively long duration of tertiary studies is that the higher education sector and particularly the universities have traditionally focused on providing long and strongly academic courses. Since the launch of the higher education reform in 2004, the situation is changing as the system is transformed into a three-cycle system consistent with the Bologna Declaration (Figure 11). Slovenia opted for a gradual implementation of the Bologna reform by the academic year 2009-10 when only post-reform programmes will be offered. Until then higher education institutions offer both pre and post-reform programmes. As only a very small number of students have so far graduated from the new system, the impact of the reform on the length of studies cannot yet be determined.

35. A second major reason for the long study times is the Slovenian system of study support which does not provide enough incentives for rapid graduation (Box 4). The level of benefits granted to students enrolled in higher education - such as subsidies for accommodation, transport and meals - appears relatively generous. Moreover, about a third of all students receive direct financial support in the form of scholarships. As a share of total public expenditure on education, Slovenia spends much more on financial aid to students than the average OECD country (Figure 12). Student loans do not currently exist in Slovenia (with the exception of loans for studies abroad) as the loans introduced in 1999 were abolished again in 2002/03 (Box 4). Higher education is in principle free for full-time students of first and secondcycle programmes, though a ministerial decree requires part-time students to pay tuition fees. Institutions have the autonomy to determine the level of tuition fees for part-time programmes themselves; in the academic year 2008/09 the fees ranged from around EUR 1800 to EUR 4000 per annum.

Figure 11. The structure of higher education in Slovenia

Before and after the reform of 11 June 2004

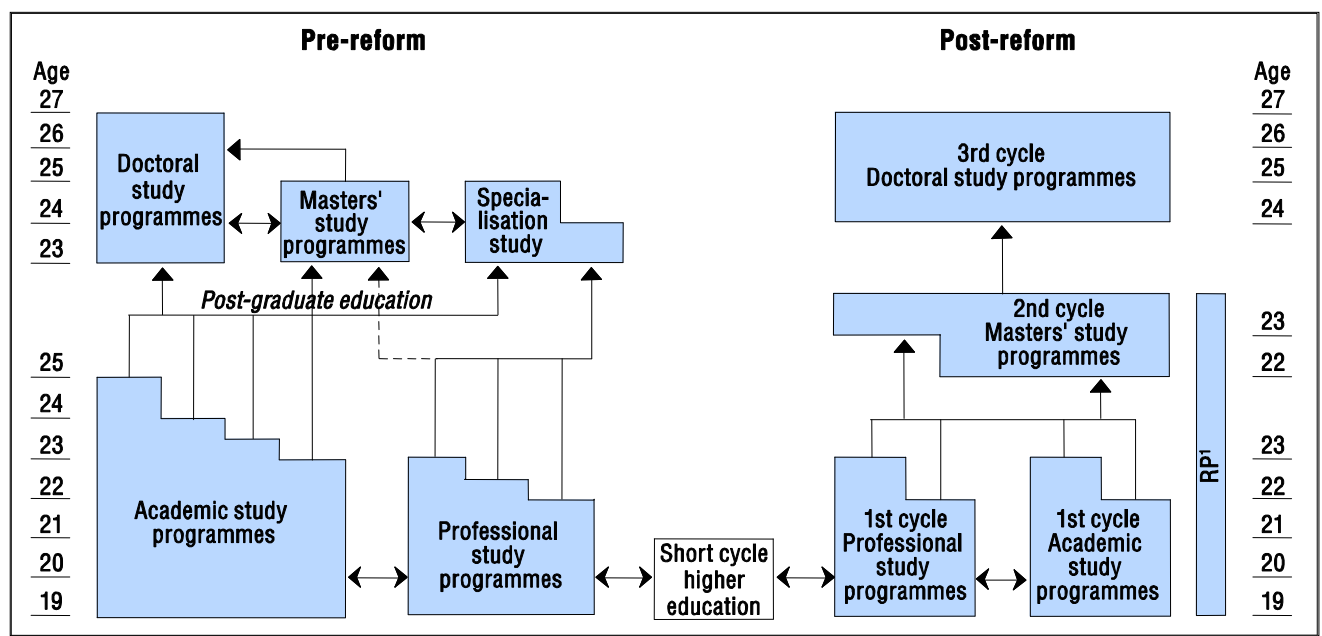

1. RP: Long non-structured masters' study programmes (e.g. EU regulated professions).

Source: Ministry of Education and Sport. 


\section{Box 4. Study support}

Students enrolled in higher education benefit from subsidised accommodation, subsidised meals (coupon system), discounts on public transportation, discounts on cultural events (such as theatre tickets) and on subscriptions to sports clubs. The only direct financial support is provided in the form of scholarships. First, state scholarships targeted at students from low income families are provided to full-time students who enrol in higher education before the age of 27 and whose gross income per family member in the previous year did not exceed $130 \%$ of the guaranteed wage. Second, academically talented students may be eligible for merit-based scholarships, so-called Zois scholarships (named after a well-known Slovenian scholar). In addition to publicly provided scholarships, there are also company scholarships offered by public and private organisations in relation to their (future) staff requirements. In 2007, 18\% of all full-time students were granted a state scholarship (of around EUR 180 per month, on average), 11\% were granted a Zois scholarship (of around EUR 210 per month, on average) and 6\% received a company scholarship (of around EUR 240 per month, on average).

In 1999 a student loan system was first introduced. Loans were offered on the basis of a contract between the student, the Employment Service of Slovenia and a bank holding a concession (an interest subsidy) awarded by the Ministry of Labour, Family and Social Affairs. Slovenian nationals who were under the age of 27 at the first enrolment, who were not employed and who did not receive any type of scholarship were eligible for the loan. As the number of applicants was very low, the scheme was abolished in 2002/03. The basic amount of a student loan was about EUR 1050 per annum in 2001, but it could be increased to a maximum amount of EUR 1580 per annum in special cases.

Figure 12. Public subsidies for tertiary education ${ }^{1}$

In per cent of total public expenditure on education, 2005

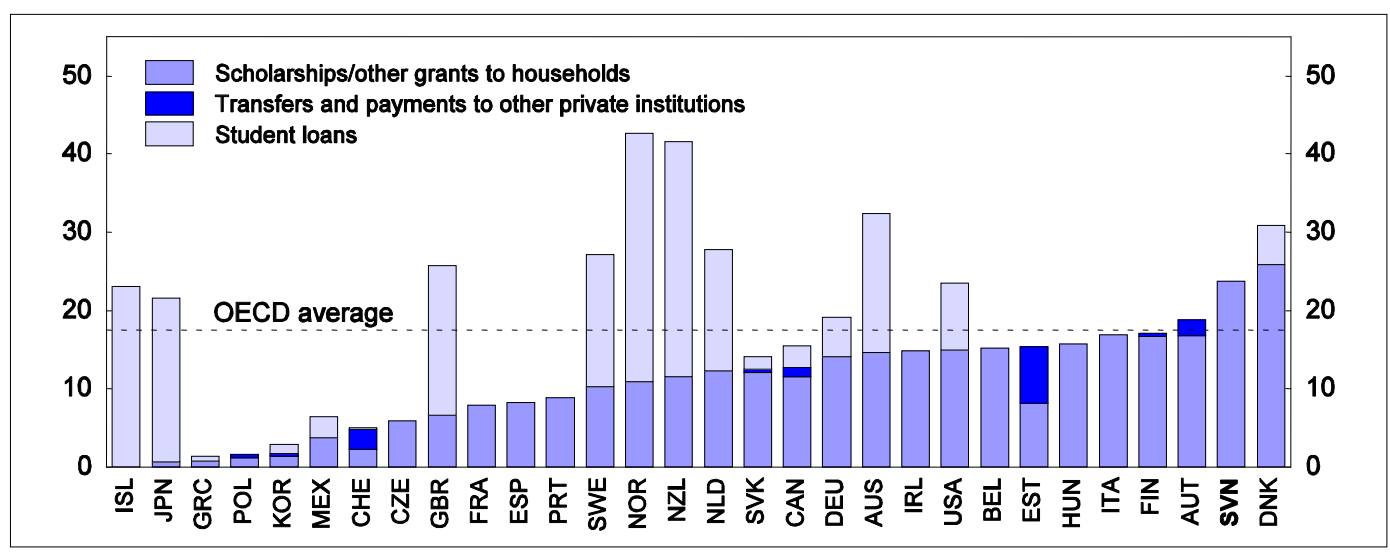

1. Public subsidies for education to households and other private entities.

Source: OECD (2008), Education at a Glance.

36. Improving the quality of higher education institutions would also contribute to shortening the duration of studies (IMAD, 2008b). The ratio of students to teaching staff, a frequently used indicator for the quality of tertiary education, has barely improved in past years and still falls short of the comparable ratios of most OECD countries (Figure 13, panel A), the main reason being the relatively low annual expenditure per student (Čelebič, 2008). In 2005, Slovenia spent USD 8500 per full-time student (in purchasing power parities) compared with an OECD average of USD 11500 (Figure 13, panel B). Improving the quality of the teaching process may reduce the number of students who have to repeat courses and prevent them from unduly prolonging their studies. 


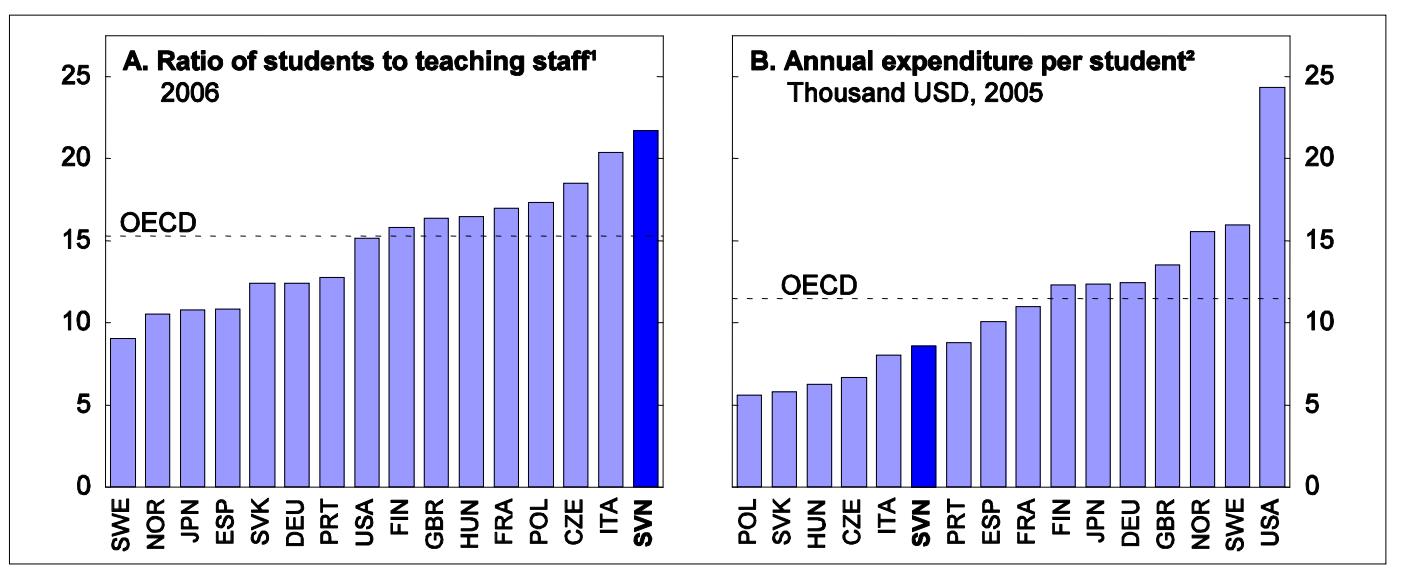

1. Based on full-time equivalents. Public institutions only for Norway; excluding independent private institutions for France.

2. Expenditure on core and ancillary services, and research and development. In equivalent US dollars converted using purchasing power parities for GDP, based on full-time equivalents. Public institutions only for Hungary, Italy, Poland, Portugal and Slovenia.

Source: OECD (2008), Education at a Glance.

37. Eligibility for student benefits, including cheap housing, should be made contingent on an annual minimum study progress. Similarly, tuition fees in tertiary education that at least partially reflect the cost of education should be introduced. This would raise the incentives for students to progress rapidly with their studies and also improve market signals between students, providers and the labour market. In addition, it would improve the funding of higher education institutions, thus contributing to a higher quality of the teaching process. To avoid deterring students, especially those from low-income families, the tuition fee system could be accompanied by publicly guaranteed student loans with repayments conditional on earnings after graduation.

\section{Preventing damage from the minimum wage}

38. The employment opportunities of youth, particularly the less skilled, might also be adversely affected by the relatively high minimum wage. Theoretically, a statutory minimum wage set at too high a level could become a barrier to employment for low-productivity workers by driving a wedge between productivity and labour costs. However, it has proven difficult to pin down the negative employment effects empirically (OECD, 2006b). Regarding the impact on the employment opportunities of young workers the empirical evidence is mixed with some studies having identified negative effects of minimum wages on youth employment, especially if combined with high non-wage labour costs (e.g. Abowd et al., 1997; Bassanini and Duval, 2006), while others have failed to do so (e.g. Stewart, 2002).

39. Slovenia has had a statutory minimum wage (which covers all sectors of the economy) since 1995, when the tripartite social agreement determined a cash figure for the lowest permissible monthly wage. Whilst the tripartite agreement concluded in 1997 raised the minimum wage by roughly the same amount as pay in general, the agreement for the period 1999-2001 stipulated an extra increase with the aim of gradually bringing the minimum wage up to $58 \%$ of the average wage in the manufacturing sector. ${ }^{15}$ During 1999-2004, the minimum wage was also adjusted in line with forecast consumer price inflation and

15. The law implementing the provisions of the social agreement for 1999-2001 introduced, for the first time, a national minimum wage in the proper sense as the validity of the part of the law that regulates the minimum wage was not limited, as previously, by the duration of the social agreement. 
by the real GDP growth rate of the previous year. As a result it increased to around $46.5 \%$ of the average wage in the private sector (54\% of the average wage in the manufacturing sector) by 2004 (Figure 14, panel A). Since 2006, the increase in the minimum wage has been decided by the government after consulting the social partners, based on forecast consumer price inflation. Since inflation came out higher than forecast in 2008 the legislation was amended to provide for an additional increase in the minimum wage of about 51/4 per cent in March 2008. When setting annual increases in the minimum wage, mistakes in forecasting inflation should not only be corrected when underestimated but also when overestimated.

40. Although the minimum wage has declined relative to the average wage in recent years, it is still fairly high by OECD standards (Figure 14, panel B) and may present a barrier to employment for young people, especially for the less-skilled. The ratio of the minimum wage to the average wage should not increase and preferably be further reduced in order to improve the employment prospects of the low-skilled young workers. The argument for reducing the relative level of the minimum wage is reinforced by target efficiency considerations (OECD, 2006b). Although the minimum wage is meant to improve the income of low-income families, a substantial proportion of workers in minimum-wage jobs are likely not to be poor, for example because other family members have earnings. And for those who risk sliding into poverty due to a relative decline in the level of minimum wages, other instruments such as in-work benefits are available that can be better targeted on low-income families. Several OECD countries have lower minimum wages for youth, for example Belgium, the Netherlands and the United Kingdom (see OECD, 2009, Table 3 for details). ${ }^{16}$ However, the empirical evidence on the employment effects of such subminima is mixed. While some studies indicate that the negative employment effects of minimum wages are smaller when sub-minimum wages exist (e.g. Neumark and Wascher, 1999; Hyslop and Stillman, 2007), others fail to detect any robust effect (e.g. Böckerman and Uusitalo, 2007).

Figure 14. Minimum wage

Per cent

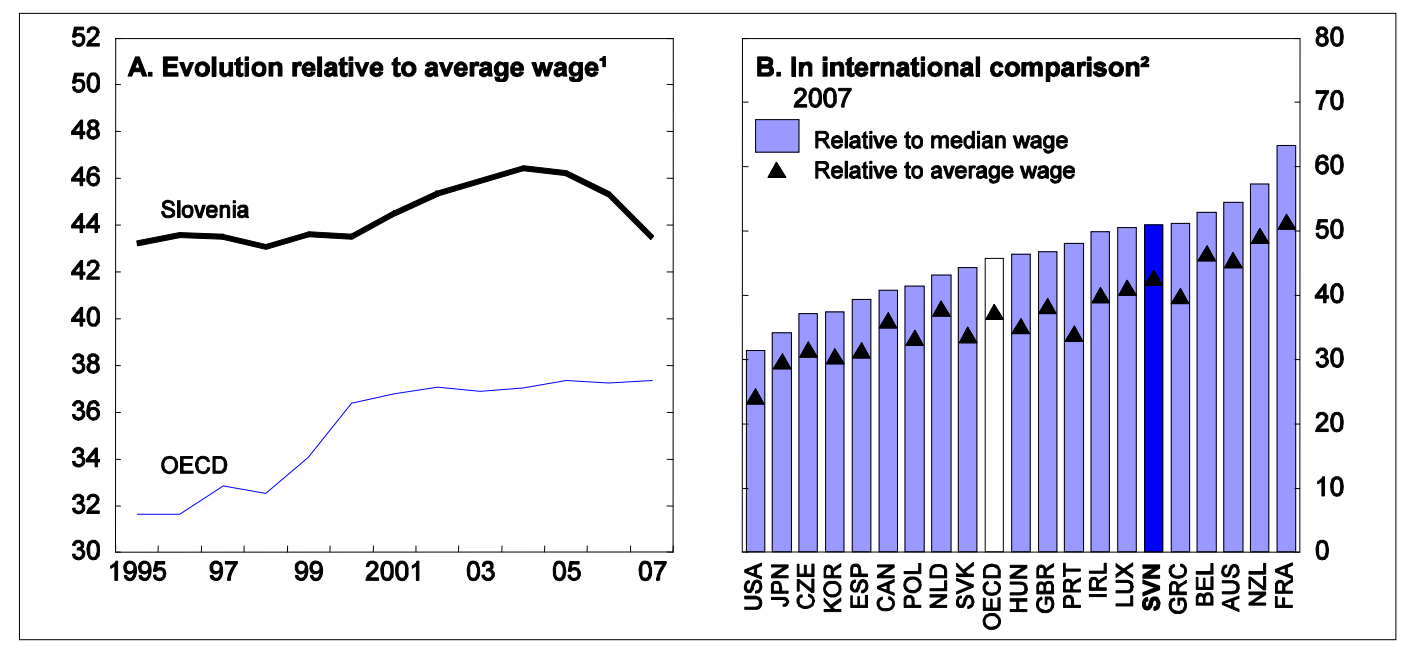

1. For Slovenia the average wage data used is the gross wage of the private sector. The OECD aggregate is an unweighted average of the 19 OECD countries shown in panel B, excluding Ireland to 2000, Slovak Republic to 1997 and United Kingdom to 1999.

2. The OECD aggregate is an unweighted average of the countries shown.

Source: OECD (2008), OECD Employment database - online version, www.oecd.org/els/employment/data and Ministry of Labour, Family and Social Affairs.

16. The Netherlands is the country with the most differentiated minimum wage for youth, ranging progressively from $30 \%$ of the statutory rate for those- aged 15 to $85 \%$ for those aged 22 . 


\section{Coping with rising labour market dualism}

41. Slovenia has made some notable progress in the past decade in easing EPL in order to improve the flexibility of its labour market (Box 1). Vodopivec et al. (2007) estimate an index of employment protection legislation for Slovenia over the period 1991 to 2004 and conclude that both the amendment to the Employment and Insurance against Unemployment Act that came into force in 1998 and the new Employment Relationships Act that came into force in 2003 had a sizable impact on EPL over that period (Table 1). Whilst the 1998 amendment to the EIUA facilitated temporary employment, the 2003 amendment to the Employment Relationships Act focused primarily on the liberalisation of regular employment and put some additional restrictions on temporary contracts. More recent amendments to the two Acts, enacted respectively in 2006 and 2007, brought about further reductions in EPL on both types of contracts.

Table 1. Employment protection legislation index

Scale of indicators 0-6, from least to most restrictive

\begin{tabular}{lcccccccc}
\hline & 1997 & 1998 & 1999 & 2000 & 2001 & 2002 & 2003 & 2004 \\
\hline EPL index overall & 4.1 & 3.1 & 3.1 & 3.1 & 3.1 & 3.1 & 2.7 & 2.7 \\
$\quad$ Regular contracts & 4.0 & 4.0 & 4.0 & 4.0 & 4.0 & 4.0 & 2.7 & 2.7 \\
$\quad$ Procedure & 5.0 & 5.0 & 5.0 & 5.0 & 5.0 & 5.0 & 3.0 & 3.0 \\
\hline Notice and severance pay & 3.1 & 3.1 & 3.1 & 3.1 & 3.1 & 3.1 & 1.8 & 1.8 \\
$\quad$ Difficulty of dismissal & 4.0 & 4.0 & 4.0 & 4.0 & 4.0 & 4.0 & 3.3 & 3.3 \\
\hline Temporary contracts & 3.8 & 1.3 & 1.3 & 1.3 & 1.3 & 1.3 & 2.0 & 2.0 \\
$\quad$ Fixed-term contracts & 2.0 & 2.0 & 2.0 & 2.0 & 2.0 & 2.0 & 2.3 & 2.3 \\
$\quad$ Temporary work agency employment & 5.5 & 0.5 & 0.5 & 0.5 & 0.5 & 0.5 & 1.8 & 1.8 \\
\hline Collective dismissals & 5.3 & 5.3 & 5.3 & 5.3 & 5.3 & 5.3 & 4.8 & 4.8 \\
\hline
\end{tabular}

Source: Vodopivec, M. et al. (2007), "Mobility of Work (Mobilnost dela)", in Dolenc. P. and M. Vodopivec (eds.), Mobilnost dela in fleksibilnost sistema plač, Fakultete za Management, Koper.

42. Despite these legislative changes, employment protection is still relatively high in Slovenia (Figure 15). The most serious problem is that EPL tends to be much stricter for regular than for temporary work as past reforms eased the use of temporary forms of employment while not going far enough in terms of increased flexibility for those under permanent contracts. The administrative procedures for individual notice and dismissal are cumbersome and the conditions under which dismissals are legitimate are stricter than in many other OECD countries. Moreover, severance payments are still relatively high (Box 1). The policy of liberalising temporary employment without a similar adjustment of permanent employment risks creating a dual labour market where some jobs are more protected than others. ${ }^{17}$ In particular groups with weak attachment to the labour market tend to suffer from a partial relaxation of EPL.

43. The share of workers with fixed-term contracts has indeed increased significantly since the liberalisation of temporary employment, from $11 \%$ in the late 1990 s to over $18 \%$ in 2007 (Figure 16, panel A). A large share of this temporary employment is involuntary with more than half of all workers employed on a temporary basis citing the inability to find a permanent job as the main reason for having a temporary one in the 2007 Labour Force Survey. Temporary employment is particularly prevalent among young workers; in 2007, more than two-thirds of those aged 15 to 24 had a fixed-term contract which is the highest share among European Union countries (Figure 16, panel B). In fact, between 2003 and 2007 the

17. Temporary contracts tend to be more common in countries with strict EPL on regular contracts even though these countries often also have relatively strict rules on temporary contracts. 
number of temporary jobs increased by more than the total number of jobs for the young, implying that the number of regular jobs actually declined during the economic upswing. A large proportion of the temporary employment by youth might be accounted for by student work (see above). The duration of fixed-term contracts is generally very short; more than $80 \%$ of all temporary workers aged 15 to 24 have a contract for less than one year (compared with $44 \%$ in the EU15).

Figure 15. Regulation of regular and temporary employment

Scale of indicators 0-6, from least to most restrictive, $2006^{1}$

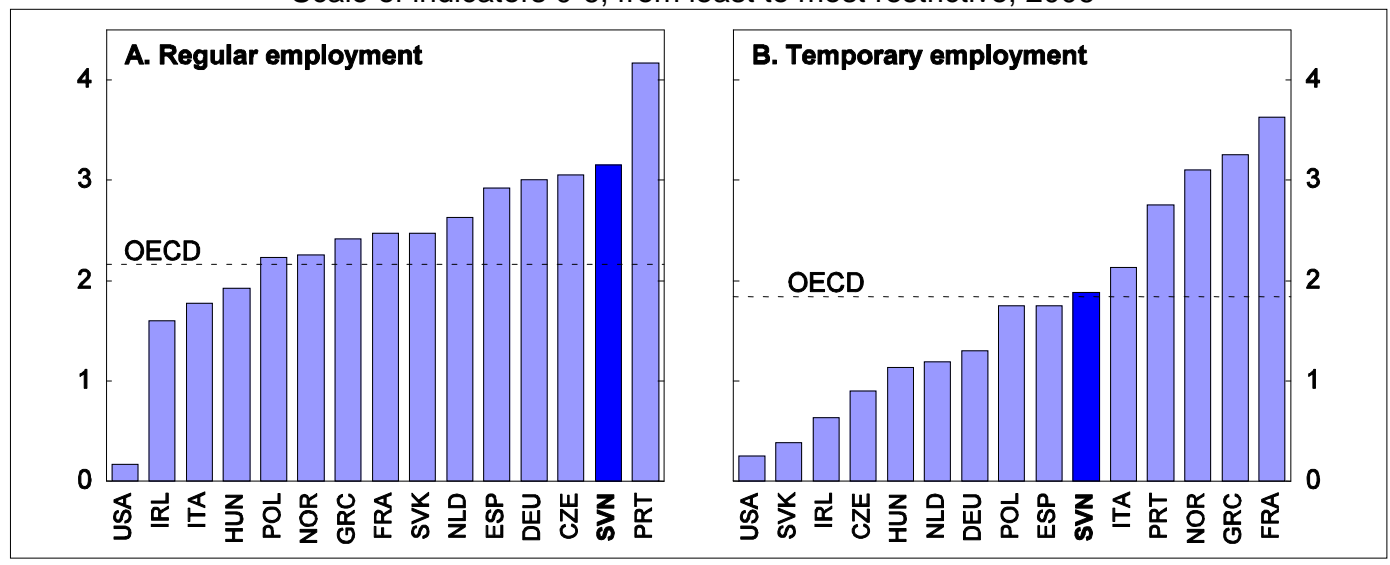

1. 2008 for Slovenia which is an OECD estimate. The OECD aggregate is an unweighted average.

Source: OECD (2006), Going for Growth, Economic Policy Reforms.

44. The large share of youth on fixed-term contracts observed in Slovenia is consistent with existing cross-country evidence showing that a larger difference in employment protection between regular and temporary contracts goes along with a higher prevalence of temporary work among youth (OECD, 2004). As the young are more likely to be subject to entry problems into the labour market than other groups of the workforce they are more likely to be disproportionately affected by the effects of EPL on firms' hiring decisions. Although a temporary job might be the first step towards a more permanent and stable job, this is not always the case and workers might get trapped in the situation of moving between temporary work and unemployment.

45. The benefits of enhancing overall firm flexibility notwithstanding, temporary work may adversely affect career progression and productivity if workers get trapped in temporary forms of employment that are typically characterised by weak job attachments and limited opportunities to upgrade human capital (OECD, 2004). The problem of labour market dualism needs to be addressed swiftly, not only for reasons of social equality, but also because of economic efficiency. Clawing back past achievements in relaxing EPL for temporary work contracts would, however, be the wrong choice. Instead, once the current economic crisis dissipates, the authorities should continue to ease EPL for regular job contracts. In particular, the administrative burden on individual notice and dismissal should be reduced and the conditions under which individual dismissals are legitimate should be relaxed. Moreover, severance pay provisions should be reformed. One option would be to follow the Austrian example and transform the traditional severance pay system into individual severance accounts (Box 5). 
Figure 16. Incidence of temporary employment

Employees with a contract of limited duration in per cent of total number of employees

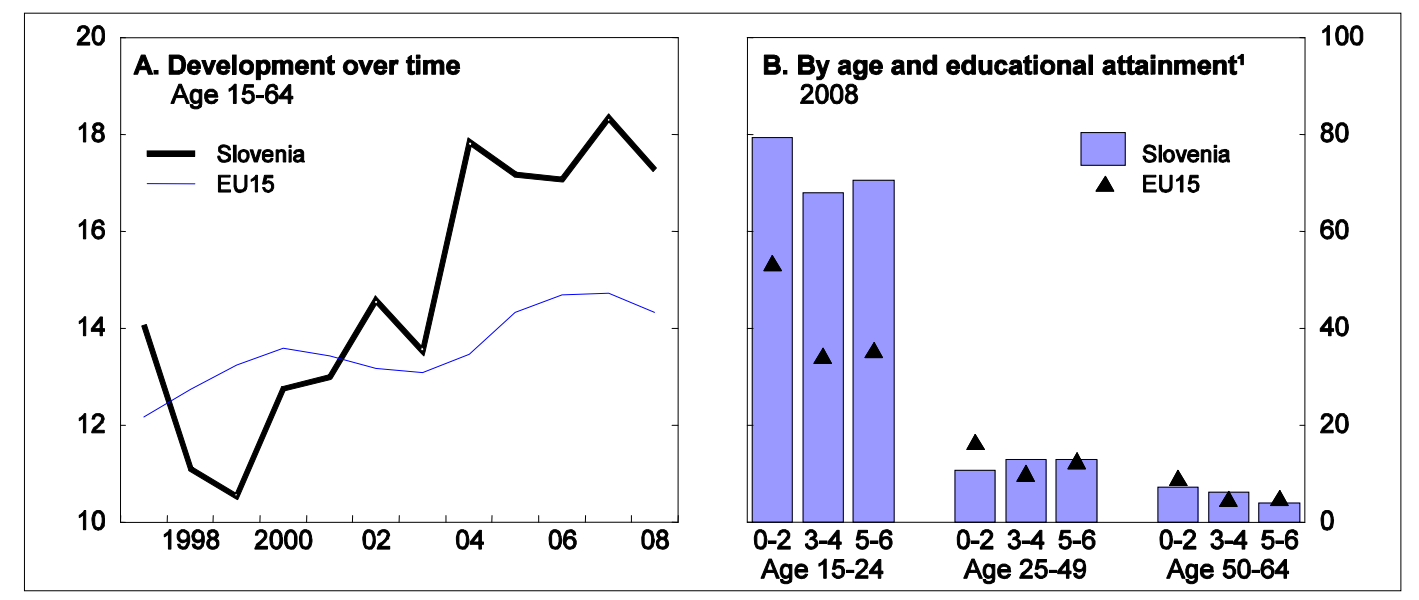

1. ISCED levels: $0-2=$ below upper secondary, 3-4 = upper secondary and post-secondary non-tertiary, 5-6 = tertiary. For Slovenia the reliability of results of the detailed unemployment data by age may be affected by the small sample size or the sampling method used.

Source: Eurostat database (2009), Labour Force Survey, May.

\section{Box 5. The Austrian severance pay reform*}

Until 2002 severance pay had to be paid to private-sector employees upon termination of the employment contract (by the employer or in mutual agreement) provided the employee had worked for the employer for at least three years. The payment amounted to two monthly wages after three years of company membership and increased with the duration of the job up to a maximum value of one yearly income after 25 years. This system was criticised for excluding workers on short-term contracts (e.g. seasonal workers) from the right to severance pay and for inhibiting labour mobility as employees lost their entitlement to severance pay in the case of self-termination. Furthermore, it was pointed out that SMEs might have liquidity problems if they were to make several severance payments simultaneously.

In 2003, the traditional severance pay system was replaced by a system of individual saving accounts. The account of each worker is funded by the employer via an untaxed payment of $1.5377 \%$ of the gross wage and is managed by an employee provision fund that invests the balance on capital markets. The payments start in the second month of the employment relationship. If the employee is dismissed after three years of job tenure, he can choose between a cash payment, further investment in the same employee provision fund or in the employee provision fund of the new employer, and transferring the respective amount as a one-time payment to a pension insurance fund. The entitlements to severance pay can thus be cumulated by an employee over his or her entire working career, serving as a form of retirement saving. Upon retirement the employee can either claim a cash payment or convert entitlements into an annuity. If the employee leaves the company voluntarily or if he is dismissed during the first three years of the job contract no cash payment can be claimed, though the claim is not lost as it can be transferred to the new job.

The reform extended the entitlement to severance pay considerably as entitlement starts after one month and neither depends on the job tenure nor on the way the employment relationship is terminated. The level of the payment now depends on the performance of the employee provision fund on the capital market, though the nominal contribution paid by the employer is guaranteed. From an employer's perspective, the new scheme avoids the one-time costs of dismissal and the uncertainty related to the size of the payment at the time of hiring. However, the contributions to the individual accounts add to labour costs.

* This box draws on Hofer, H. (2006), "The Severance Pay Reform in Austria" (Abfertigung Neu), CESifo DICE Report, No. 4/2007, CESifo Group, Munich; and Koman, R., U. Schuh and A. Weber (2005), "The Austrian Severance Pay Reform: Toward a Funded Pension Pillar", Empirica, Vol. 32, No. 3-4, Springer Netherlands. 
46. Facilitating access of temporary workers to appropriate training could also help to improve their chances of finding a permanent job. Research has shown that job training is strongly correlated with opportunities for temporary workers to move into permanent jobs (Grubb et al., 2007). In this regard, the recommendations regarding lifelong learning might help to mitigate the dual labour market issue. Finally, the problem of student work needs to be addressed. The preferential treatment of student work may induce firms to hire students instead of regular workers and thus intensify labour market duality. The reimbursement of social security contributions to employers who hire unemployed persons younger than 26, first-time job-seekers whose occupation is in excess supply, or people under 28 who have been unemployed for 24 months (introduced in 2006) is likely to mitigate the negative effects somewhat. However, subsidising regular work by young graduates in order to prevent it from being crowded out by subsidised student work is very costly. Instead, the authorities should consider phasing out the preferential treatment of student work as recommended above.

\section{Box 6. Main recommendations to improve the functioning of the labour market}

Mitigating the effect of the economic crisis without jeopardising the long-run functioning of the labour market

- $\quad$ Ensure that the subsidy scheme for shorter working hours is phased out once the crisis dissipates. In the meantime, make eligibility temporary in nature.

- Avoid any measures that are detrimental to the long-term functioning of the labour market, such as tightening the rules for immigrant workers.

\section{Boosting the labour force participation of the elderly}

- $\quad$ The increase in pensionable ages for women foreseen in the 1999 Pension and Disability Insurance Act should be accelerated.

- $\quad$ The pensionable age should be further increased for both genders, possibly taking into account advice from an expert commission when deciding about the size of the necessary increase. Once the increase has been phased in, and life expectancy at the full pensionable age has reached a suitable level, additional increases in the pensionable age should be linked to gains in life expectancy and the length of the pension qualifying period should be raised accordingly. The retirement conditions for women should be aligned with those for men.

- $\quad$ Ensure that the penalties/bonuses for early/late retirement are actuarially neutral. Abolish the upper limit on the number of additional working years beyond the statutory retirement age during which bonuses are paid (currently set at three years).

- $\quad$ Phase out remaining possibilities to retire prior to the pensionable age. Limit the use of informal pathways to early retirement by reviewing the disability and long-term sickness insurance schemes to ensure that eligibility conditions are sufficiently tight and adequately monitored, and by reducing the unemployment benefit duration for long-term unemployed older workers towards the general length of 12 months once the current economic crisis dissipates.

- $\quad$ Further strengthen the link between pension benefits and working careers by basing benefits on full lifetime average earnings.

- $\quad$ Allow people to receive wage and pension income at the same time. At the very least, relax the rules for partial retirement and phase out the tax disincentives.

- Ensure that the inter-ministerial working group which was set up to discuss the implementation of the Lifelong Learning Strategy quickly develops a plan to put the strategy into action. Evaluate the impact of adult education programmes on labour market outcomes. Swiftly set up and implement the Active Ageing Strategy. 
$\mathrm{ECO} / \mathrm{WKP}(2009) 60$

\section{Rising the employment rates of youth}

- Make eligibility for student benefits, including cheap housing, contingent on an annual minimum study progress.

- Introduce tuition fees in tertiary education. To avoid deterring students, especially those from low-income families, consider complementing the tuition fee system by publicly guaranteed student loans with repayments conditional on earnings after graduation.

- $\quad$ Consider phasing out the preferential treatment of student work or at the very least impose an upper age limit.

- When setting annual increases in the minimum wage, correct mistakes in forecasting inflation not only when underestimated but also when overestimated. Do not increase the ratio of the minimum wage to the average wage and preferably further reduce it.

\section{Coping with rising labour market dualism}

- $\quad$ Once the current economic crisis dissipates, continue to ease employment protection legislation for regular job contracts. In particular, reduce the administrative burden on individual notice and dismissal, relax the conditions under which individual dismissals are legitimate and reform severance pay provisions. 
ECO/WKP(2009)60

\section{BIBLIOGRAPHY}

Abowd, J.M. et al. (1997), "Minimum Wages and Youth Employment in France and the United States", NBER Working Paper, No. 6111, National Bureau of Economic Research, Cambridge, MA.

Bassanini, A. et al. (2005), "Workplace Training in Europe”, IZA Discussion Paper, No. 1640, Institute for the Study of Labour, Bonn.

Bassanini, A. and R. Duval (2006), "Employment Patterns in OECD Countries: Reassessing the Role of Policies and Institutions", OECD Social, Employment and Migration Working Paper, No. 35 and OECD Economics Department Working Paper, No. 486, OECD, Paris.

Behaghel, L. and N. Greenan (2005), "Training and Age-Biased Technical Change: Evidence from French Micro Data", CREST Working Paper, No. 6, Centre de Recherche en Économie et Statistique, INSEE, Paris.

Böckerman, P. and R. Uusitalo (2007), "Minimum Wages and Youth Employment: Evidence from the Finnish Retail Sector", Labour Institute for Economic Research Discussion Paper, No. 238, Labour Institute for Economic Research, Helsinki.

Burniaux, J-M., R. Duval and F. Jaumotte (2003), "Coping with Ageing: A Dynamic Approach to Quantify the Impact of Alternative Policy Options on Future Labour Supply in OECD Countries", OECD Economics Department Working Paper, No. 371, OECD, Paris.

Burtless, G. (2009), "Preparing the Labour Market for an Ageing Population: Designing Public Policy to Increase Labour Force Participation", in Holzmann, R., L. MacKellar and J. Repanšek (eds.), Pension Reform in South-Eastern Europe, World Bank, Washington, DC.

Čelebič, T. (2008), “Access Quality and Efficiency of Tertiary Education in Slovenia Post-2000”, IMAD Working Paper, No. 5/2008, Institute of Macroeconomic Analysis and Development, Ljubljana.

Duval, R. (2003), "The Retirement Effects of Old-age Pension Systems and Other Social Transfer Programmes in OECD countries", OECD Economics Department Working Paper, No. 370, OECD, Paris.

ECB (European Central Bank) (2008), "Labour Supply and Employment in the Euro Area Countries: Developments and Challenges", Occasional Paper, No. 87, ECB, Frankfurt.

Grubb, D., J.K. Lee and P. Tergeist (2007), "Addressing Labour Market Duality in Korea”, OECD Social, Employment and Migration Working Paper, No. 61, OECD, Paris.

Gustman, A.L. and T.L. Steinmeier (2004), "Minimum Hours Constraints, Job Requirements and Retirement", NBER Working Paper, No. 10876, National Bureau of Economic Research, Cambridge, MA. 
Høj, J. et al. (2006), "The Political Economy of Structural Reform - Empirical Evidence from OECD Countries", OECD Economics Department Working Paper, No. 501, OECD, Paris.

Hyslop, D. and S. Stillman (2007), "Youth Minimum Wage Reform and the Labour Market in New Zealand", Labour Economics, Vol. 14, No. 2, Elsevier BV, Amsterdam.

IMAD (Institute of Macroeconomic Analysis and Development) (2008a), "Challenges of the Labour Market from the Aspect of Flexicurity”, Economic issues 2008, IMAD, Ljubljana.

IMAD (2008b), "Efficient Use of Knowledge for Economic Development and High-quality Jobs", Development Report 2008, Institute of Macroeconomic Analysis and Development, Ljubljana.

Martin, J.P. and D. Grubb (2001), "What Works and for Whom: A Review of OECD Countries' Experiences with Active Labour Market Policies", Swedish Economic Policy Review, Vol. 8, No. 2, Stockholm.

Neumark, D. and W. Wascher (1999), "A Cross-National Analysis of the Effects of Minimum Wages on Youth Employment", NBER Working Paper, No. 7299, National Bureau of Economic Research, Cambridge, MA.

OECD (2004), OECD Employment Outlook, OECD Publishing, Paris.

OECD (2006a), Live Longer, Work Longer, Ageing and Employment Policies, OECD Publishing, Paris.

OECD (2006b), OECD Employment Outlook: Boosting Jobs and Incomes, OECD Publishing, Paris.

OECD (2007), Pensions at a Glance, OECD Publishing, Paris.

OECD (2008), Education at a Glance, OECD Publishing, Paris.

OECD (2009), Jobs for Youth - Japan, OECD Publishing, Paris.

Queisser, M. and E.R. Whitehouse (2006), "Neutral or Fair?: Actuarial Concepts and Pension-System Design", OECD Social, Employment and Migration Working Paper, No. 40, OECD, Paris.

Stewart, M.B. (2002), "The Impact of the Introduction of the UK Minimum Wage on the Employment Probabilities of Low Wage Workers", Warwick Economics Research Paper, No. 630, University of Warwick, Warwick.

Vodopivec, M. et al. (2007), "Mobility of Work (Mobilnost dela)", in Dolenc. P and M. Vodopivec (eds.), Mobilnost dela in fleksibilnost sistema plač, Fakultete za Management, Koper.

Vodopivec, M. and P. Dolenc (2009), "Live Longer, Work Longer: Making it Happen in the Labour Market", in Holzmann, R., L. MacKellar and J. Repanšek (eds.), Pension Reform in South-Eastern Europe, World Bank, Washington, DC.

ZPIZ (Zavod za pokojninsko in invalidsko zavarovanje Slovenije) (2008), "Monthly Statistics Overview", Institute of Pension and Invalidity Insurance of Slovenia, Ljubljana. 
ECO/WKP(2009)60

ANNEX A1.

\section{ESTIMATING A TIME-VARYING NAIRU BY MEANS OF THE KALMAN FILTER}

1. The estimation of the non-accelerating inflation rate of unemployment (NAIRU) follows the approach outlined in Gianella et al. (2008). Using the Kalman filter, the NAIRU is derived from its ability to explain inflationary developments within a Phillips-curve framework, subject to constraints on its evolution over time. The Phillips curve equation relates the change in consumer price inflation (measured by the change in the harmonised consumer price index) to real import price inflation (weighted by the import content of consumption to account for the economy's rising openness) and the unemployment gap, defined as the difference between the NAIRU and the unemployment rate. ${ }^{1}$ Assuming dynamic homogeneity to hold, the relationship takes the following form:

$$
\Delta \pi_{t}=\sum_{j=1}^{m} \alpha_{j}(L) \Delta \pi_{t-j}+\sum_{j=0}^{n} \beta_{j} M G S_{t-j}^{S H}\left(\pi_{t-j}^{M G S}-\pi_{t-j}\right)+\gamma\left(U_{t}-U_{t}^{*}\right)+\delta D_{V A T}+v_{t}
$$

where $\pi$ is domestic inflation, $M G S^{S H}$ is the import content of consumption, ${ }^{2} \pi^{M G S}$ is import price inflation (goods and services), $U$ is the unemployment rate, $U^{*}$ is the NAIRU, $D_{V A T}$ is a dummy variable meant to capture the introduction of value added tax (VAT) in July 1999, and $v_{t} v_{t}$ is the residual. The appropriate lag structure for the three right-hand-side inflation variables is determined by starting with four lags each and then dropping statistically insignificant lags. Data on domestic inflation and unemployment are obtained from respectively Eurostat and the Statistical Office of Slovenia; all other data are taken from the OECD Economic Outlook database.

2. There is no unique way of using the Kalman filter to estimate the NAIRU and a variety of assumptions may be adopted to describe the stochastic process it follows. Following Gianella et al. (2008), the NAIRU is inferred from two transition equations specifying the time-series properties of respectively the NAIRU and the unemployment gap. The NAIRU is modelled as a simple random walk process which seems appropriate given that the unemployment rate series is integrated of order one. The transition equation for the NAIRU thus takes the following form:

$$
U_{t}^{*}=U_{t-1}^{*}+\varepsilon_{t}
$$

where the error term $\varepsilon_{t}$ is assumed to be normally distributed with mean zero and variance $\sigma_{\varepsilon}^{2}$ and uncorrelated with the error term of the Phillips-curve equation $v_{t}$.

3. In addition, a law of motion is imposed on the gap between the NAIRU and the unemployment rate to ensure that the unemployment rate converges to the NAIRU in the absence of shocks. This assumption is consistent with the work by Friedman (1968) on the natural rate hypothesis implying that the unemployment rate cannot deviate permanently from its natural rate. The unemployment gap is assumed to follow a second-order autoregressive process. This additional restriction allows inferring the level of the

1. The change in the real oil price was initially also included in the equation but did not turn out significant.

2. Calculated as $M G S_{t}^{S H}=M_{t} /\left(Y_{t}+M_{t}-X_{t}\right)$ where $M, X$ and $Y$ denote imports, exports and domestic output. 
NAIRU not only on the basis of information on inflationary pressures, but also based on the unemployment rate dynamics themselves. The transition equation for the unemployment gap can be written as:

$$
U_{t}-U_{t}^{*}=\psi(L)\left(U_{t-1}-U_{t-1}^{*}\right)+\zeta_{t}
$$

where the error term $\zeta_{t}$ is normally distributed with mean zero and variance $\sigma_{\zeta}^{2} \sigma_{\zeta}^{2}$ and uncorrelated with $\varepsilon_{t}$. Although not necessary for the solution of the model, constraints are imposed on the sum of the autoregressive parameters to ensure sensible time-series properties of the unemployment gap. ${ }^{3}$

4. Applying the Kalman filter to the model outlined above requires assumptions about several parameters. First, the values and variances of the two state variables (the NAIRU and the unemployment gap) in the initial period have to be pre-specified. The initial value of the NAIRU is set equal to the average unemployment rate around the first year of the sample and the initial value of the unemployment gap is set equal to the difference between the unemployment rate in the initial period and the prior for the NAIRU. Second, assumptions are made about the relative variances of the three residuals $\sigma_{v}^{2}, \sigma_{\varepsilon}^{2}$ and $\sigma_{\zeta}^{2}$. The variance of the error term in the transition equation of the NAIRU relative to the one of the error term in the Phillips-curve equation (the signal-to-noise-ratio) determines the smoothness of the NAIRU series with a smaller ratio resulting in a less volatile NAIRU. While in principle the Kalman filter allows estimating the three variances together with the other parameters of the model, this often leads to NAIRU series that are too smooth (Richardson et al., 2000). As a consequence, the variances are typically fixed in empirical applications. Following the suggestion by Gordon (1997), the signal-to-noise ratio is chosen such that it allows the NAIRU to move around freely but rules out sharp quarter-to-quarter gyrations.

5. The model is estimated over the period 1997Q2 to 2008Q3, the longest period for which all data are available. The unemployment gap is found to have a significant influence on consumer price inflation suggesting that the derived NAIRU can be interpreted as the unemployment rate consistent with stable inflation (Table A1.1). The sacrifice ratio implied by the estimated coefficients is equal to 0.59 which is consistent with the values obtained by Gianella et al. (2008) for other OECD countries. The estimates suggest that the NAIRU declined throughout the sample period, reaching around 5 $1 / 2$ per cent in the third quarter of 2008 (Figure 2). The sharp drop in unemployment in recent years appears to have been to a large extent a cyclical phenomenon as the unemployment rate fell considerably below the NAIRU.

Table A1.1. Phillips curve estimates

\begin{tabular}{lcc|lc}
\hline \multicolumn{1}{c}{ Variable } & Coefficient & Standard error ${ }^{1}$ & \multicolumn{2}{c}{ Diagnostic statistics } \\
\hline$\Delta \pi_{t-1}$ & -0.892 & 0.098 & Adj. $\mathrm{R}^{2}$ & 0.706 \\
$\Delta \pi_{t-2}$ & -0.800 & 0.103 & $\sigma_{\varepsilon}^{2} / \sigma_{v}{ }^{2}$ & 5.000 \\
$\Delta \pi_{t-3}{ }_{M G S_{t}{ }^{S H}\left(\pi_{\mathrm{t}}{ }^{\mathrm{MGS}}-\pi_{t}\right)}$ & -0.732 & 0.063 & Sacrifice ratio & 0.570 \\
$U_{t}-U_{t}{ }^{*}$ & 0.205 & 0.108 & Serial correlation (lags 1 to 4, $p$-value) & 0.906 \\
$D_{V A T}$ & -0.376 & 0.193 & Normality ( $p$-value) & 0.380 \\
\hline
\end{tabular}

1. Newey-West heteroskedasticity consistent standard errors.

3. The value chosen for the sum of the autoregressive parameters is equal to 0.75 . 
ECO/WKP(2009)60

\section{BIBLIOGRAPHY}

Friedman, M. (1968), “The Role of Monetary Policy”, American Economic Review, Vol. 58, No. 1, American Economic Association.

Gianella, C. et al. (2008), "What Drives the NAIRU? Evidence from a Panel of OECD Countries", OECD Economics Department Working Paper, No. 649, OECD, Paris.

Gordon, R.J. (1997), “The Time-varying NAIRU and its Implications for Economic Policy”, Journal of Economic Perspectives, Vol. 11, No. 1, American Economic Association.

Richardson, P. et al. (2000), "The Concept, Policy Use and Measurement of Structural Unemployment: Estimating a Time Varying NAIRU Across 21 OECD Countries", OECD Economics Department Working Paper, No. 250, OECD, Paris. 
ECO/WKP(2009)60

\section{WORKING PAPERS}

The full series of Economics Department Working Papers can be consulted at www.oecd.org/eco/working papers/

718. What drives sovereign risk premiums? An analysis of recent evidence from the Euro Area (July 2009) David Haugh, Patrice Ollivaud, and David Turner

717. The English National Health Service: an economic health check (July 2009) Peter Smith and Maria Goddard

716. Financial stability in the United Kingdom: Banking on prudence (July 2009) Philip Davis

715. Economic growth and the role of taxation- disaggregate data (July 2009) Gareth D. Myles

714. Economic growth and the role of taxation - Aggregate data (July 2009) Gareth D. Myles

713. Economic growth and the role of taxation - Theory (July 2009) Gareth D. Myles

712. The effectiveness of education and health spending among Brazilian municipalities (July 2009) Luiz de Mello and Mauro Pisu

711. The bank lending channel of monetary transmission in Brazil: A VECM approach (July 2009) Luiz de Mello and Mauro Pisu

710. How does decentralised minimum-wage setting affect unemployment and informality? The case of Indonesia

(July 2009) Margherita Comola and Luiz de Mello

709. Intergenerational social mobility in European OECD countries (July 2009) Orsetta Causa, Sophie Dantan and Åsa Johansson

708. Equity in student achievement across OECD countries: an investigation of the role of policies (July 2009) Orsetta Causa and Catherine Chapuis

707. Intergenerational social mobility

(July 2009) rsetta Causa and Åsa Johansson

706. Taxes or grants: what revenue source for sub-central governments?

(July 2009) Hansjörg Blöchliger and Oliver Petzold

705. The spending power of sub-central governments: a pilot study (July 2009) Steffen Bach, Hansjörg Blöchliger and Dominik Wallau

704. Price and volume elasticities of Brazilian foreign trade: A profit function approach (July 2009) Luiz de Mello and Mauro Pisu 
ECO/WKP(2009)60

703. Current account sustainability in Brazil: A non linear approach (July 2009) Luiz de Mello and Matteo Mogliani

702. The incentives to participate in and the stability of international climate coalitions: a game-theoretic approach using the WITCH Model

(July 2009) Valentina Bosetti, Carlo Carraro, Enrica De Cian, Romain Duval, Emanuele Massetti and Massimo Tavoni

701. The economics of climate change mitigation: how to build the necessary global action in a costeffective manner

(June 2009) Jean-Marc Burniaux, Jean Chateau, Rob Dellink, Romain Duval and Stéphanie Jamet

700. Capital inflows, household debt and the boom bust cycle in Estonia (June 2009) Zuzana Brixiova, Laura Vartia and Andreas Wörgötter

699. The effect of financial crises on potential output: new empirical evidence from OECD countries (May 2009) Davide Furceri and Annabelle Mourougane

698. Employment - productivity trade-off and labour composition (May 2009) Hervé Boulhol and Laure Turner

697. Labour market flexibility in Estonia: what more can be done? (May 2009) Zuzana Brixiova

696. Structural policies to overcome geographic barriers and create prosperity in New Zealand (April 2009) Yvan Guillemette

695. Ten years of product market reform in OECD countries - insights from a revised PMR indicator (April 2009) Anita Wölfl, Isabelle Wanner, Tomasz Kozluk and Giuseppe Nicoletti

694. Structural reforms and the benefits of the enlarged eu internal market (April 2009) Jens Arnold, Peter Höller, Margaret Morgan and Andreas Wörgötter

693. Co-benefits of climate change mitigation policies: literature review and new results (April 2009) Johannes Bollen, Bruno Guay, Stéphanie Jamet and Jan Corfee-Morlot

692. The impact of monetary and commodity fundamentals, macro news and central bank communication on the exchange rate: Evidence from South Africa (April 2009) Balázs Égert

691. Assessing the impacts of climate change: a literature review (April 2009) Stéphanie Jamet and Jan Corfee-Morlot

690. The determinants of employment and earnings in Indonesia: a multinomial selection approach (April 2009) Margherita Comola and Luiz de Mello

689. Inflation responses to recent shocks: do $G 7$ countries behave differently (April 2009) Lukas Vogel, Elena Rusticelli, Pete Richardson, Stéphanie Guichard and Christian Gianella 